\title{
Environmental factors controlling biomass development of seagrass meadows of Zostera noltei after a drastic decline (Arcachon Bay, France)
}

\author{
Cognat Mathis ${ }^{1,2}$, Ganthy Florian ${ }^{1,{ }^{*}}$, Auby Isabelle ${ }^{1}$, Barraquand Frédéric ${ }^{3}$, Rigouin Loic ${ }^{1}$, \\ Sottolichio Aldo ${ }^{2}$
}

${ }^{1}$ Ifremer LER/AR, Quai du Commandant Silhouette, FR33120, Arcachon, France

2 UMR CNRS 5805 EPOC, Allée Geoffroy St Hilaire, CS50023, FR33615 Pessac Cedex, France

${ }^{3}$ Chaire ETI Labex COTE, Université de Bordeaux, Bât. B2 - Allée Geoffroy St-Hilaire, FR33615

Pessac, France

* Corresponding author : Florian Ganthy, email address : florian.ganthy@ifremer.fr

\begin{abstract}
:
The relative impact of light, depth, hydrology, hydrodynamics, sediment and nutrients on growth of the seagrass Zostera noltei was investigated in Arcachon Bay, where the extent of seagrass beds has been decreasing for 20 years. A comprehensive multi-parameter survey of 9 sites was conducted monthly over one year. A three-parameter logistic growth model was fitted to biomass data to unravel the relative contributions of environmental factors on seagrass growth. The present study highlights the fact that, in addition to the dominant positive effect of light on plant growth, the hydrological and hydrodynamic parameters were important drivers for $Z$. noltei growth at the scale of the whole Bay. At the scale of individual sites, other factors such as macroalgal mats or micro-topography (such as presence of tidal pools) may also influence seagrass growth. The statistical model also suggested that the different factors contribute differently to $Z$. noltei growth in different sites. Finally, as the model is not able to predict biomass accurately for sites that received very little light, and seagrasses in these sites having higher chlorophyll content and longer shoots, we suspect that adaptation to low light condition was at play. In a global context of seagrass beds decline, our study provides a framework to disentangle the site-specific effects of physical and biological drivers on seagrass seasonal growth.
\end{abstract}

\section{Highlights}

- Beyond light, hydrology and hydrodynamics mainly control Z. noltei growth. Seagrasses acclimation to low light conditions for deeper sites. Site-specific effects of physical drivers on seagrasses growth.

Keywords : Physical parameters, Light, Hydrodynamics, Adaptation, Statistical growth model 


\section{INTRODUCTION}

Seagrass meadows are found worldwide in coastal areas and represent one of the most valuable coastal resources for the ecosystem services they provide (Costanza et al., 1997; Orth et al., 2006). Seagrass meadows are highly productive, and are well-known ecosystem engineers (Bos et al., 2007; van der Heide et al., 2007). They dampen hydrodynamic energy from waves (Paul and Amos, 2011) and currents (Winddows et al., 2008), promote sediment deposition and reduce resuspension (Ganthy et al., 2015), and therefore tend to create stable habitats for many species (Duffy, 2006). Despite their ability to change their own physical environment, they are very sensitive to environmental quality (Orth et al., 2006) and a worldwide decline of seagrasses was observed during the last century (Orth et al., 2006; Waycott et al., 2007). Multiple factors can contribute to their decline (Orth et al. 2006): sediment and nutrient runoff, physical disturbance, invasive species, disease, fishing practices, aquaculture, algal bloom, global warming, etc.

In this global context, an important decline in the extent of seagrass beds was also recently reported in Arcachon Bay (South French Aquitain Coast, Figure 1). This shallow semienclosed bay has a total area of $174 \mathrm{~km}^{2}$ with $70 \%$ of intertidal flats. These mudflats are colonized by dwarfgrass (Z. noltei), while eelgrass (Z. marina) occupies the shallow subtidal sector around the channel edges (Figure 1). Plus et al. (2010) showed that between 1989 and 2007, the total area of Z. noltei meadows has decreased by $33 \%$ (from $68.5 \mathrm{~km}^{2}$ to $45.7 \mathrm{~km}^{2}$ ) while the area of Z. marina meadows has decreased by $74 \%$ (from $3.7 \mathrm{~km}^{2}$ to $1.0 \mathrm{~km}^{2}$ ). Concurrently to Zostera spp. decline, suspended sediment concentration increased (ARCHYD hydrological network, Ifremer 2017). This increased turbidity is unlikely to be due to an intensification in the wind-waves regime, as wind energy did not change significantly during this period (data from Météo France weather station). Furthermore, local authorities reported 
a massive accumulation of mud over eastern sandy beaches and channels. Because Z. noltei beds are known as efficient sinks of fine sediments in Arcachon Bay (Ganthy et al., 2013; Kombiadou et al., 2014), observed changes in sediment dynamics are suspected of being one of the direct consequences of Zostera decline.

Light available for photosynthesis is commonly considered to be the principal factor limiting Zostera spp. maximum depth distribution (Duarte, 1991; Villazán et al., 2016). Thus, an increase in suspended sediment concentration in the bay would contributes to a selfamplification mechanism (i.e. positive feedback process; Carr et al., 2010; Suykerbuyk et al., 2016). However, previous studies showed that Zostera, to a certain extent, is able to accommodate to various light conditions through biochemical (changes in pigment content) or through structural response (changes of leaf length and width) (Auby et al., 1999; Li et al., 2013; Ochieng et al., 2010; de los Santos et al., 2010).

Wave-induced stress and currents are often considered as the main factors controlling the upper depth limit of seagrass beds by preventing their establishment (Balke et al., 2014) and damaging or uprooting of plants (Fonseca \& Bell, 1998; Koch, 2001). Fonseca \& Bell (1998), among others, also showed that seagrass fragmentation was related to current speed and wave disturbance. Thus, changes in hydrodynamics induced by Zostera spp. decline in Arcachon Bay may also have exacerbated the regression. Although Zostera spp. are known to acclimate to strong hydrodynamics (through changes in their morphometry, architecture and mechanical traits; Koch et al., 2006), de los Santos et al. (2010) indicated that such adaptation responses to current velocities make them more vulnerable to light deprivation.

Temperature is also known to influence Z. noltei growth and mortality. Auby et al. (1999) and Plus et al. (2005) showed an increase of dwarfgrass photosynthetic efficiency in Arcachon Bay when temperature increased from 7 to $25^{\circ} \mathrm{C}$. Moreover, Massa et al. (2009) highlighted 
an important negative effect of heat shocks (temperatures around $39^{\circ} \mathrm{C}$ ) on Z. noltei shoot survival and photosynthetic efficiency. Depth (hypsometry) can modulate the effects of a heat shock on intertidal Zostera spp. as it directly determines out-of-water time and subsequent desiccation effects (Leuschner et al., 1998). In Arcachon Bay, Zostera spp. decline began after two summers of heatwaves (2003 and 2006), with unusual maximum water temperatures $\left(>36^{\circ} \mathrm{C}\right)$ recorded in the eastern shallow waters where the decline started. Thus, it is suspected that these conditions explain the initiation of die off (Auby et al., 2011).

In Arcachon Bay, the total annual freshwater input is about $65010^{6} \mathrm{~m}^{3}$ and leads to seasonal and spatial variations in salinity ranging between 22 and 35 . Effects of salinity on this euryhaline species seem negligible. Indeed, Z. noltei can develop in a large range of salinity conditions, from marine to brackish waters down to a salinities of 5 (Fernández-Torquemada and Sánchez-Lizaso, 2011; Vermaat et al., 2000).

Nutrient availability can limit seagrass growth in oligotrophic environments (Short, 1987). Conversely, high nutrient loading may enhance biomass of opportunistic macroalgae, epiphytes and phytoplankton, which reduces light availability for seagrasses (Brun et al., 2003; McGlathery, 2001; Orth et al., 2010). It also increases organic input in sediments, leading to enhanced NH4, NH3 and sulphide concentrations that can be toxic for seagrasses (Burkholder et al., 1992; Govers et al., 2014). Furthermore, Soissons et al. (2018) showed for Z. noltei that the mechanical traits of their leaves changed pending on nutrient availability. For instance, under more eutrophic conditions, leaves become more vulnerable to physical forces. Nutrients concentrations in Arcachon bay exhibits a decreasing gradient from inner to outer parts of the system due to the dilution of riverine inputs. In eastern areas, eutrophic conditions may occur, leading to proliferation of green algae (mostly Monostroma and Enteromorpha). By contrast, in western parts of the bay where oceanic water dominates, 
nutrient concentrations are relatively lower so that these areas can be considered as oligotrophic (Castel et al., 1996).

As for nutrients, the eastern parts of the bay are more contaminated by herbicides and biocides than the western part. Herbicides mainly come from the Eyre river (corn farming watershed), while biocides contamination comes from antifouling paints and can be important in the bay, given the large number of boats for recreational use, shellfish farming and fishing (Auby \& Maurer, 2004; Auby et al., 2007, 2011; Fauvelle, 2012). These contaminants mainly affect seagrasses by altering photosynthesis processes (Chesworth et al., 2004; Gao et al., 2011; Nielsen \& Dahllöf, 2007). Furthermore, high temperatures $\left(28^{\circ} \mathrm{C}\right)$ enhance the effect of contaminants (herbicides + copper), leading to growth inhibition and differential gene expression (Gamain et al., 2017).

From this overview it appears that in the Arcachon Bay, the reasons for the triggering of Zostera spp. reduction seem established, but the role of physical factors in the resulting cycle involving seagrass and sedimentary processes remains unclear. This is a major obstacle to understanding the ongoing seagrass decreasing trend, and to prioritize management actions for Zostera spp restoration. A large in situ data collection effort was required, in order to assess and sort the relative contributions of environmental factors (light availability, temperature, hydrodynamics, bed sediments characteristics) favouring/reducing Z. noltei biomass development within Arcachon Bay. To achieve this objective, nine contrasted seagrass beds were monitored over a year, by measuring monthly biological, sedimentological and physical parameters. Hydrological and hydrodynamics conditions could also be characterised at each site from a numerical fine-scale hydrodynamic model (Kombiadou et al., 2014). We compared th relative contribution of the different factors using a statistical growth model. 


\section{MATERIALS AND METHODS}

\subsection{Study area and site description}

Arcachon Bay is located on the South French Atlantic Coast $\left(44^{\circ} 40^{\prime} \mathrm{N}, 1^{\circ} 10^{\prime} \mathrm{W}\right.$, Figure 1). Its latitude induces an oceanic climate, with average air temperatures varying between about 8 ${ }^{\circ} \mathrm{C}$ in winter and $22{ }^{\circ} \mathrm{C}$ in summer (Météo France weather station), while average water temperature ranges from about $8{ }^{\circ} \mathrm{C}$ in winter up to $23{ }^{\circ} \mathrm{C}$ in summer with large spatiotemporal fluctuations (Ifremer, 2017). 


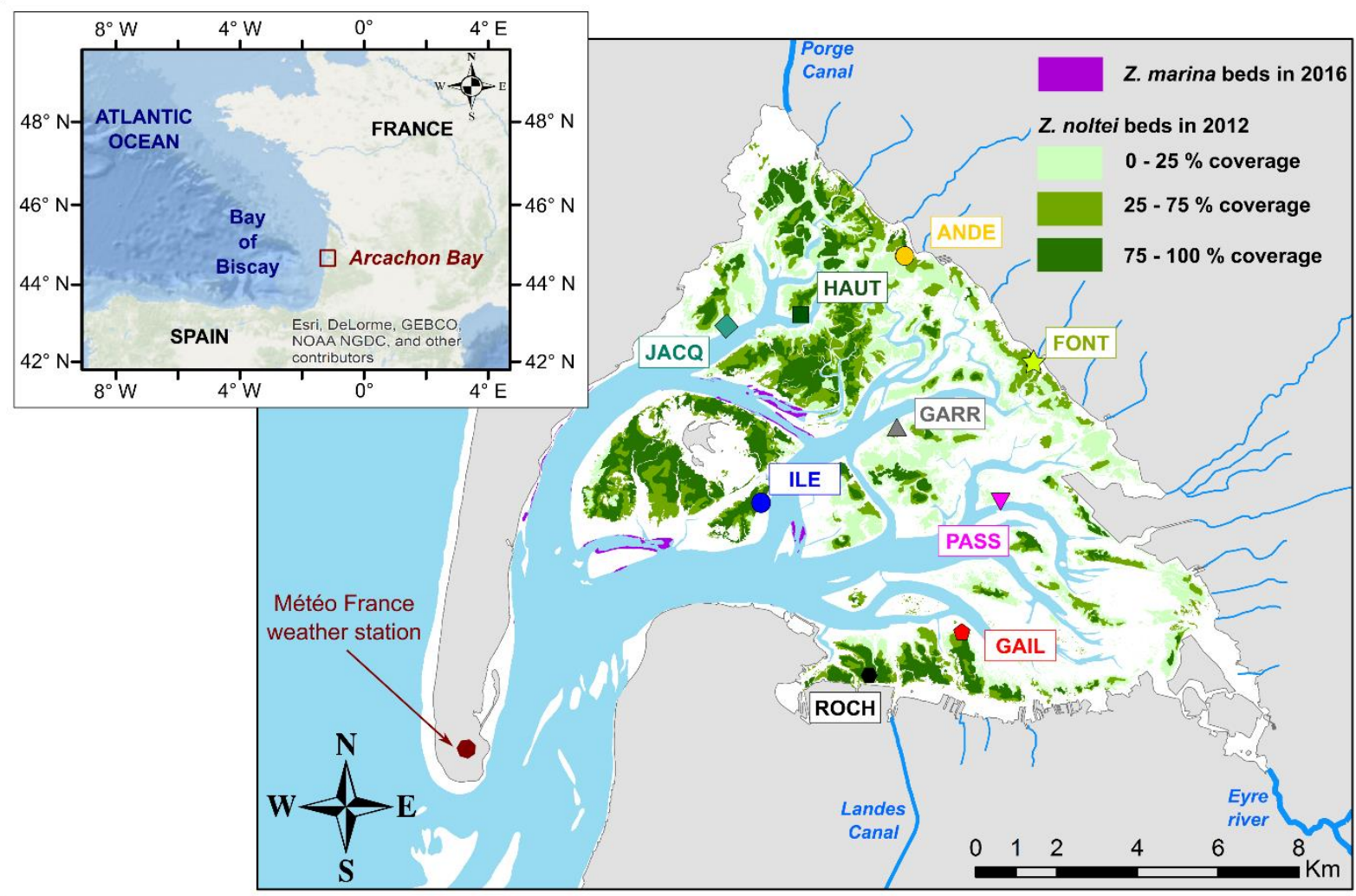

Figure 1. General location of Arcachon Bay and of the nine sampling sites. Subtidal areas are shown in sky blue. Maps showing the extent of Z. marina and Z. noltei beds indicate their coverage in 2016 and 2012 respectively.

\section{(Figure 1 width: 1.5 column; color in print)}

A wide two-channel inlet allows water exchange between the bay and the ocean, mainly forced by semi-diurnal tides (tidal range varying between 0.8 and $4.6 \mathrm{~m}$ ). Tidal currents are very strong within main channels (up to $2 \mathrm{~m} \cdot \mathrm{s}^{-1}$ ) and are weaker within secondary channels and on tidal flats $\left(0.1\right.$ to $\left.0.5 \mathrm{~m} . \mathrm{s}^{-1}\right)$. Despite the winter storms occurring in the bay of Biscay, that induce heavy swells along the Aquitaine coast, the well-developed ebb delta and the multiple sand banks limit the propagation of ocean waves into the bay (Pedreros et al., 2008). Most of the waves are therefore induced by local wind (Parisot et al., 2008). Sediment characteristics in the bay reflect the prevailing impact of tides with presence of gravels and coarse sand within main channels, sand and muddy sand within secondary channels, and 
sandy mud and mud on intertidal flats. The tidal pumping leads to an outer-inner turbidity gradient.

The spatio-temporal investigation of relationships between Z. noltei standing stocks and environmental factors was performed through a one-year field survey (December 2015 December 2016). Monthly measurements were performed at 9 intertidal sites distributed over the whole of the Bay (Figure 1), selected for their different depths, environmental conditions and seagrass cover (Table 1).

Maximum water depth (high spring tide, $\mathrm{Hwat}_{\max }, \mathrm{m}$ ) ranges from $3.44 \mathrm{~m}$ for the deepest site (GARR) to $2.09 \mathrm{~m}$ for the shallowest site (FONT). These values reflect the span of Z. noltei depth distribution within the bay (Auby \& Labourg, 1996). Each site consisted of a $10 \mathrm{~m}$ by $10 \mathrm{~m}$ square area $\left(100 \mathrm{~m}^{2}\right)$ which was delimited by bamboo rods at the beginning of the survey (first site inspection).

\subsection{Environmental parameters}

At each site, mean daily light received by plants $\left(P A R_{\text {site, }}\right.$ mol photons. $\mathrm{m}^{-2}$.day $\left.{ }^{-1}\right)$, mean temperature $\left(T_{\text {mean }},{ }^{\circ} \mathrm{C}\right)$, averaged immersion time $\left(I_{\text {time }}\right.$, hour.day $\left.{ }^{-1}\right)$, and $75^{\text {th }}$ percentiles of a modified relative wave exposure index ( $R E I_{75}$, no unit) were computed for each survey period (i.e. the time between two site inspections) from high frequency measurements. Simultaneously, bulk dry density $\left(\rho_{d r y}\right.$, in $\left.\mathrm{kg} \cdot \mathrm{m}^{-3}\right)$, median grain size $\left(D_{50}, \mu \mathrm{m}\right)$ and organic matter content $\left(O M_{\text {sed }}\right.$, in $\left.\%\right)$ of the uppermost $5 \mathrm{~cm}$ of bed sediments were obtained at each site and site inspection from sediment samples. For a full description of the experimental protocol used to measure these environmental parameters, see Appendix A. 
Mean daily irradiance $\left(\operatorname{Ir}_{0}, \mathrm{~J} . \mathrm{cm}^{-2}\right.$.day $\left.{ }^{-1}\right)$ was computed from total daily irradiance retrieved from the Météo-France weather station located on Cap Ferret (Figure 1), averaged over a survey period.

To complete this collection of environmental variables, additional physical parameters were derived from the MARS3D numerical model. This hydrodynamic model (Lazure and Dumas, 2008) was implemented on Arcachon Bay by Plus et al. (2009) and improved by Kombiadou et al. (2014). We used a 3-dimensional version (horizontal resolution of $235 \mathrm{~m}$ ) that explicitly takes into account the hydrodynamic modification induced by Z. noltei beds. A two month simulation was performed using an empirically-based tide (FES2012 solution, Carrère et al., 2013) to capture the natural variability of tidal forcing. Freshwater inputs were set as constant equal to yearly average values. Seagrass beds were parameterised using the latest seagrass map (2012) and mid-development (early summer) seagrass characteristics (leaf densities, width and length).

First, $75^{\text {th }}$ percentiles of near-bed velocities $\left(V_{75}, \mathrm{~m} . \mathrm{s}^{-1}\right.$, averaged from the bed to $0.5 \mathrm{~m}$ above the bed) were computed for each site because high current velocities are expected to cause uprooting or damage seagrass leaves. Secondly, local flushing (so-called water residence) time $\left(F_{t o t}\right.$, day) which corresponds to the time required for the replacement of $67 \%$ of local water by waters coming from the ocean or from the rivers (Koutitonsky et al., 2004), was computed over the whole model domain and then extracted for each site. A second simulation, was performed without freshwater inputs, to compute local oceanic flushing time ( $F_{\text {sea }}$, day). In the latter case, water could only be renewed by sea water. By subtracting $F_{\text {sea }}$ from $F_{t o t}$, we obtained $F_{r i v}$ (day) that can be equated to the local impact of rivers. Values of $F_{\text {riv }}$ are positive, and indicate the decrease of oceanic flushing time induced by rivers. 


\subsection{Seagrass biological parameters}

At every sampling time, the area where seagrasses were present $\left(V_{\text {area }}, \%\right)$ was visually estimated as a percentage of the total surface area of the site $(100 \mathrm{~m})$. In order to estimate leaf cover $(\mathrm{Cov}, \%)$ in vegetated areas, 5 quadrats $(0.5 \times 0.5 \mathrm{~m})$ were randomly placed on seagrass meadows and photographed for image analysis using image processing software (Image J) following the protocol for the European Water Framework Directive (Auby et al., 2014). The extents of leaf cover obtained were then averaged over the five replicates.

Typical biometric parameters (above-ground biomass, $B_{\text {leaf }}$, below-ground biomass, $B_{\text {root }}$, shoot density $D_{\text {shoot }}$, and shoot length, $H_{\text {shoot }}$ ) were measured from three replicates following a protocol fully detailed in Appendix A. Finally, leaf chlorophyll-a $\left(C h l_{a}, \mathrm{mg}_{\mathrm{g}} \mathrm{DW}^{-1}\right)$ and chlorophyll-b $\left(C h l_{b}, \mathrm{mg} . \mathrm{g} \mathrm{DW}^{-1}\right)$ contents, as well as carbon $\left(C_{\text {leaf }}, \%\right)$, nitrogen $\left(N_{\text {leaf }}, \%\right)$ and phosphorus $\left(P_{\text {leaf }}, \%\right)$ contents were determined from seagrass leaves collected 10 meters around the site area (see Appendix A for a detailed protocol).

\subsection{Data analysis and seagrass growth modelling}

Differences between sites and surveys were tested for all measured variables (biometry, chlorophyll and nutrient contents, sediment characteristics), using a two-way analysis of variance (ANOVA, using SigmaPlot ${ }^{\circledR}$ 12.5). Differences between sites for model-derived variables $\left(V_{75}, F_{\text {sea }}\right.$ and $\left.F_{r i v}\right)$ were tested with one-way ANOVA. The reader is referred to Appendix B for further details on spatio-temporal variability of measured parameters.

\subsubsection{Statistical model description}


In order to assess and sort the relative contributions of environmental factors controlling $Z$. noltei growth in Arcachon Bay, a statistical growth model was built. Among numerous growth models that have been developed for plants over the years, the logistic (three parameters or more) growth model is the most commonly utilized (Paine et al., 2012). It describes an S-shaped biomass dynamic, where an increase in biomass leads to a slowdown of biomass growth, so that biomass eventually reaches an asymptote.

The basic three-parameter logistic growth rate (per biomass unit) model is given by Eq.1:

$$
\frac{1}{B_{\text {leaf }}} \frac{d B_{\text {leaf }}}{d t}=r\left(1-\frac{B_{\text {leaf }}}{K}\right)
$$

where $B_{\text {leaf }}$ is leaf biomass, $r$ is the maximum growth rate and $K$ indicates the value of the theoretical maximal possible biomass. In a biomass growth context, this means that the rate of growth per unit biomass declines linearly from $r$ when biomass is 0 to 0 when biomass goes $K$. For now, we consider $r$ as a constant but it was varied for model fitting. Below, we operationalize the model by transforming it to discrete-time.

Writing down the per unit biomass growth rate as a linear function of biomass gives (Eq. 2):

$\frac{1}{B_{\text {leaf }}} \frac{d B_{\text {leaf }}}{d t}=\frac{d \ln \left(B_{\text {leaf }}\right)}{d t}=r-b B_{\text {leaf }}$

with $b=r / K$ the coefficient responsible for the slowdown of growth when biomass increases.

Eq. 2 is the approximately equivalent to the discrete-time version given in Eq. 3:

$$
\ln \left(\frac{B_{\text {leaf }}}{B_{\text {leaf }}}\right) \approx r-b B_{\text {leaf }} t
$$

Now, we relate biomass to per capita growth with Eq.4:

$$
y_{t}=\ln \left(\frac{B_{\text {leaf }_{t+1}}}{B_{\text {leaf }_{t}}}\right)=\ln \left(B_{\text {leaf }_{t+1}}\right)-\ln \left(B_{\text {leaf }_{t}}\right)
$$

with $y_{t}$ the relative growth rate, which we measure from the data. 
We can now relate $y_{t}$ to $B_{t}$ statistically through Eq. 5 which is easily fitted to data using a classic linear regression:

$$
y_{t}=r-b B_{\text {leaf }}+\varepsilon_{t}
$$

with $\varepsilon_{\mathrm{t}} \approx \mathrm{N}\left(0, \sigma^{2}\right)$

For this study, we assume that the maximum growth rate, $r$, is affected by various covariates. Since $b$ is constant, this means that the carrying capacity $\mathrm{K}=\mathrm{r} / \mathrm{b}$ can vary among sites. The link to covariates can be made explicit by decomposing $r$ (Eq. 6)

$$
r=r_{0}+c_{1} V 1_{t, s}+c_{2} V 2_{t, s} r=r_{0}+c_{1} V 1_{t, s}+\cdots+c_{i} V i_{t, s}(6)
$$

Where $r_{0}$ is the site-independent growth rate, $V i_{t, s}$ are time and site dependent variables and $c_{i}$ are coefficients obtained from multiple regression. The full model becomes:

$$
B_{\text {leaf }_{t+1}}=B_{\text {leaf }_{t}}+e^{\left(r_{0}+c_{1} V 1_{t, s}+\cdots+c_{i} V i_{t, s}-b B_{\text {leaf }}\right)} \text { (7) }
$$

Although it is possible to introduce a high number of environmental variables within the model, Paine et al. (2012) recommend sticking to very simple growth models with few covariates. This is especially applicable to our study, where time series have a limited length. For this reason, we aim at predicting biomass using two models: the first, where only one environmental variable is taken into account and a second, with two variables. Environmental variables may be closely interdependent. For instance, light reaching plants depends on hypsometry and hydrodynamics, which modifies sediment dynamics and thus water clarity. For this reason, it is of primary importance to remove collinearity between multiple environmental variables contributing to a given model (Dormann et al., 2013; Graham et al., 2003). In order to do this, we introduce within the model the sequential regression method (Graham et al., 2003). This method is composed of the two following steps: (1) identification of a sequence of importance for the explanatory variables on the basis of biological questioning; (2) computation of the independent contribution of each explanatory variable, 
with the second variable regressed against the first (most important), and the residuals of this regression used as the second variable.

As a first step, the main seasonal environmental variables $\left(T_{\text {mean }}, I r_{0}\right.$ and $\left.P A R_{\text {site }}\right)$ were tested to choose the first model variable. The local light received by plants $\left(P A R_{\text {site }}\right)$, which integrates both seasonal and site effects, produced the best biomass predictions (see Appendix C for further details). It was thus selected as the first variable for the model. In a second step, we tested alternatively the second model variable among the many other possibilities (Table 2).

For each tested variable all data (surveys and replicates) from all the sites $(n=297)$ were used to perform the model regression. Model predictions were then computed for each replicate (providing for each site one time-series per replicate). Statistical estimation of prediction quality were computed over the three replicates. For better readability, when predictions were plotted, they were averaged over the three replicates.

First, statistical estimators for model prediction quality were computed over all sites, providing the relative contributions of environmental factors across the Bay. Second, statistical estimators were computed for each site, providing site-specific relative contributions of factors.

All modelling steps were coded in Python, and the curve_fit function from Scipy package was used for regressions; this function performs a non-linear least-squares using the LevenbergMarquardt algorithm.

\subsubsection{Statistics for model evaluation}

In order to quantify model reliability, the following four metrics were used: 
- AICc: the corrected Akaike information criterion is an approximately unbiased estimator of the expected Kullback-Leibler information (Aho et al, 2014).

- BIC: the Bayesian information criterion (Aho et al, 2014).

- RMSE: the Root Mean Squared Error (Hyndman and Koehler, 2006).

- MASE: the Mean Absolute Scaled Error (Hyndman and Koehler, 2006).

For all these metrics, the lower the values, the more parcimonious the model.

\section{RESULTS}

\subsection{Spatio-temporal variability of environmental factors}

Immersion time $\left(I_{\text {time }}\right)$, ranged from 10.6 to 14.1 hour.day $^{-1}$ for seven of the nine sites (Table 1), while extremely high values were found for the two deepest sites: JACQ $\left(I_{\text {time }}=16.7\right.$ hour.day $\left.{ }^{-1}\right)$ and GARR $\left(I_{\text {time }}=20.7\right.$ hour.day $\left.{ }^{-1}\right)$. Percentile of modelled current velocities $\left(V_{75}\right)$ ranged from 0.07 to $0.47 \mathrm{~m} . \mathrm{s}^{-1}$ (Table 1). Five sites (ANDE, FONT, ROCH, HAUT and JACQ) were exposed to velocities lower than $0.3 \mathrm{~m} . \mathrm{s}^{-1}$, while for four sites (GARR, PASS, GAIL and ILE) velocities were higher than $0.3 \mathrm{~m} . \mathrm{s}^{-1}$. Flushing times $\left(F_{\text {sea }}\right.$; Table 1$)$ ranged from 16.1 days at the western site (ILE) to more than 23.5 days at eastern sites (HAUT, ANDE and FONT). Quite similar patterns were observed for the impact of rivers $\left(F_{r i v}\right.$; Table 1) with values ranging from 1.5 days (ILE) to more than 3 days (PASS, HAUT, ANDE and FONT).

The yearly average of sedimentological parameters $\left(D_{50}\right.$ and $\left.\rho_{d r y}\right)$ indicated that sites ranged from sandy-mud (ANDE, JACQ and ROCH) to muddy-sand (ILE), with the highest organic matter content $\left(O M_{s e d}=6.83 \%\right)$ for the muddiest site, ANDE, and the lowest $\left(O M_{\text {sed }}=1.50 \%\right)$ 
for the sandiest site, ILE (Table 1). Not surprisingly, these differences in bed sediment characteristics reflect hydrodynamics parameters (velocity and wave exposure index).

Irradiance received at the Cap Ferret weather station $\left(I r_{0}\right)$ varied seasonally (Figure 2a), with lowest values during winter $\left(0.5 \mathrm{~kJ} . \mathrm{cm}^{-2}\right.$.day $\left.{ }^{-1}\right)$ and highest values during summer $\left(2.25 \mathrm{~kJ} . \mathrm{cm}^{-}\right.$ ${ }^{2} \cdot$ day $\left.^{-1}\right)$. Concerning the local light effectively received by plants $\left(P A R_{\text {site }}\right.$, Figure $\left.2 \mathrm{a}\right)$, the main shape of the curve highlights similar patterns to $I r_{0}$. Although the local light effectively received by plants $\left(P A R_{\text {site, }}\right.$, Figure $\left.2 \mathrm{a}\right)$ showed similar temporal variability, significant differences between sites were found (Figure 2a). For example, in August, light at GAIL (about 80 mol photons. $\mathrm{m}^{-2}$. day ${ }^{-1}$ ) was more than two times higher than in GARR (about 30 mol photons. $\mathrm{m}^{-2} \cdot \mathrm{day}^{-1}$ ). During July, a very low value (about 17 mol photons. $\mathrm{m}^{-2} \cdot \mathrm{day}^{-1}$ ) was observed at ANDE. Time-series of mean temperature $\left(T_{\text {mean }}\right)$ varied from $9.5^{\circ} \mathrm{C}$ in winter to $24.2{ }^{\circ} \mathrm{C}$ in summer, while overall recorded temperatures over the studied period range ranged from -3.8 to $46.1{ }^{\circ} \mathrm{C}$ (Figure2b). For the wave exposure index $\left(R E I_{75}\right)$, the spatial variability was significant (Figure 2c), while no general clear seasonal signal was observed. Relative wave exposure $\left(R E I_{75}\right)$ values at ANDE and FONT were low (about 1) while GARR, GAIL and ILE exhibited relatively high values (around 3.5). For further details on spatio-temporal variability of environmental parameters, the reader is referred to Appendix B. 

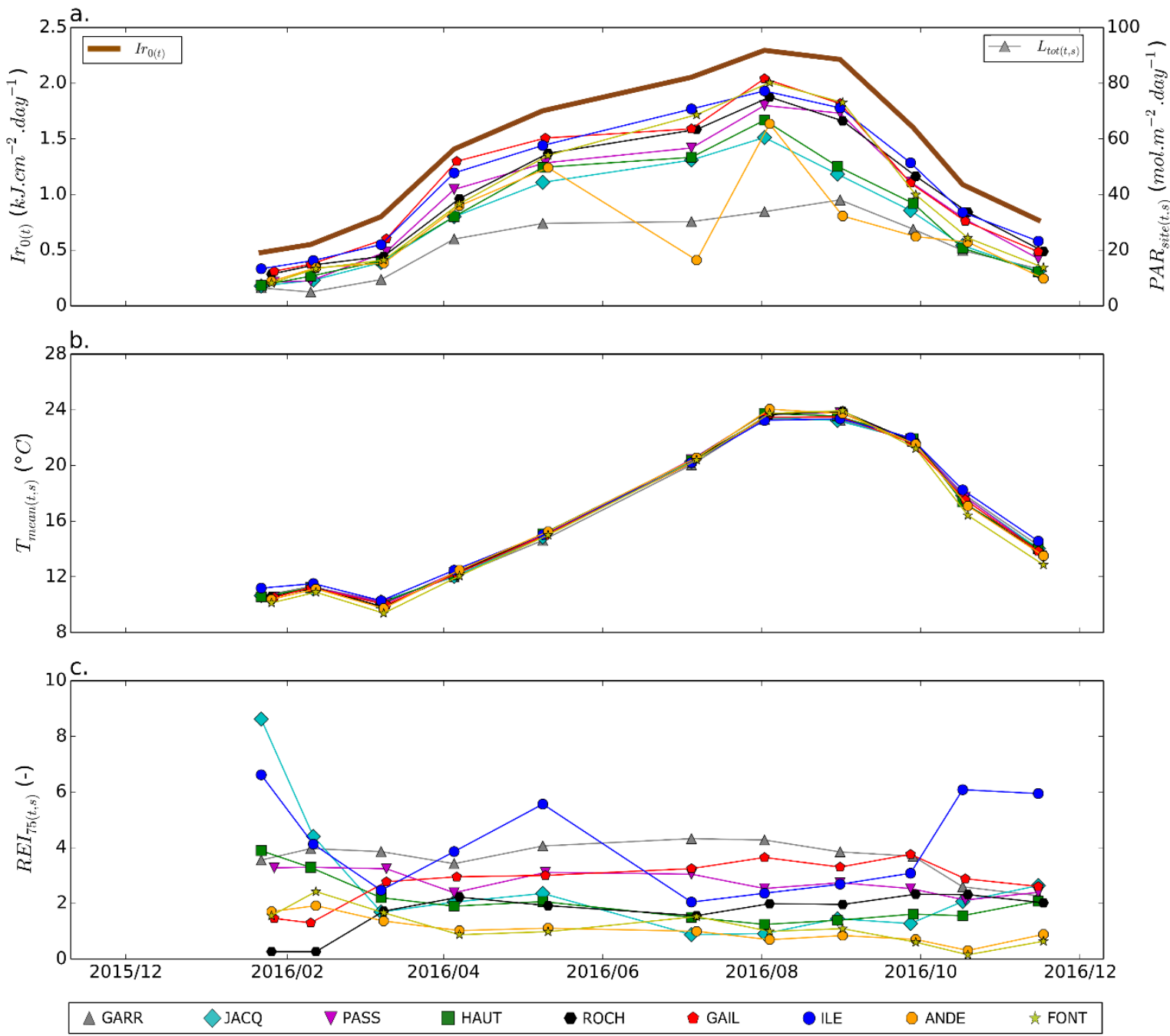

Figure 2: Time-series of (a.) irradiance at Cap-Ferret weather station and local PAR received at each site; (b.) mean temperature; (c.) relative wave exposure index (percentile 75) for each site.

(Figure 2 width: 2 columns; color online only)

\subsection{Spatio-temporal variability of biological factors}

The yearly average aboveground biomass $\left(B_{\text {leaf }}\right.$, Table 1$)$ ranged from $31.4 \pm 22.4 \mathrm{~g}$ Dw.m ${ }^{-2}$ (PASS) to $123.7 \pm 84.8 \mathrm{~g}$ Dw.m ${ }^{-2}$ (FONT). Site ANDE also exhibited low aboveground biomass $\left(32.0 \pm 15.4 \mathrm{~g}\right.$ Dw. $\left.\mathrm{m}^{-2}\right)$. By contrast, the belowground biomass $\left(\boldsymbol{B}_{\text {root }}\right)$ showed a lower 
spatial variability than aboveground biomass (from $22.8 \pm 8.9 \mathrm{~g}$ Dw. $\mathrm{m}^{-2}$ at PASS to $66.0 \pm$ $25.2 \mathrm{~g} \mathrm{Dw} \cdot \mathrm{m}^{-2}$ at HAUT). Shoot densities ( $D_{\text {shoot }}$, Table 1$)$ were generally comprised between about $9.610^{3}$ shoot.m ${ }^{-2}$ (GARR and ILE) and about $12.210^{3}$ shoot.m $^{-2}$ (GAILL and FONT). However, relatively lower values were measured at PASS $\left(7.5810^{3}\right.$ shoot.m $\left.{ }^{-2}\right)$. The yearlyaveraged values of shoot length $\left(H_{\text {shoot }}\right.$, Table 1$)$ ranged between $0.09 \pm 0.03 \mathrm{~m}(\mathrm{ROCH}$ and ANDE) to $0.13 \pm 0.05 \mathrm{~m}$ (GARR) for eight of the nine sites, while site FONT had longer shoots $(0.17 \pm 0.06 \mathrm{~m})$.

The carbon content measured within seagrass leaves $\left(C_{\text {leaf }}\right.$, Table 1$)$ showed yearly averaged values ranging from $362 \pm 30.3 \mathrm{mg}$. $\mathrm{g} \mathrm{DW}^{-1}$ (PASS) to about $400 \mathrm{mg}$. $\mathrm{g} \mathrm{DW}^{-1}$ (GAIL and ANDE). Sites JACQ and GAIL exhibited the lowest nitrogen contents $\left(N_{\text {leaf }}, 30.5 \mathrm{mg}^{\left.\mathrm{g} \mathrm{DW}^{-1}\right)}\right.$ while maximum values were measured at sites GARR and $\mathrm{ROCH}$ with values of 33.5 and $33.8 \mathrm{mg}$. $\mathrm{g} \mathrm{DW}^{-1}$ respectively (Table 1$)$. The phosphorus content $\left(P_{\text {leaf }}\right.$, Table 1$)$ was comprised between $2.9 \pm 1.1 \mathrm{mg} . \mathrm{g} \mathrm{DW}^{-1}$ (ILE) and $4.9 \pm 1.7 \mathrm{mg}$. $\mathrm{g} \mathrm{DW}^{-1}$ (ANDE). Seven sites showed chlorophyll-a contents $\left(C h l_{a}\right.$, Table 1$)$ around $5.7 \mathrm{mg} . \mathrm{g} \mathrm{Dw}^{-1}$, while lowest and highest values were obtained for site ILE $\left(5.17 \pm 0.92 \mathrm{mg} . \mathrm{g} \mathrm{Dw}^{-1}\right)$ and GARR $\left(6.44 \pm 0.75 \mathrm{mg} . \mathrm{g} \mathrm{Dw}^{-1}\right)$ respectively. The lowest value of chlorophyll-b $\left(C h l_{b}\right.$, Table 1) was obtained at site PASS $\left(1.75 \pm 0.28 \mathrm{mg} . \mathrm{g} \mathrm{Dw}^{-1}\right)$ while highest values were found for sites ROCH and FONT (about $2.3 \mathrm{mg}$. $\left.\mathrm{g} \mathrm{Dw}^{-1}\right)$. The total chlorophyll content $\left(C h l_{a+b}\right)$ followed similar patterns than $C h l_{a}$ contents with about $7.7 \mathrm{mg}$. $\mathrm{g} \mathrm{DW}^{-1}$ for most of sites, with relatively lower contents at ILE and GAIL (about 7.2 mg. $\mathrm{g} \mathrm{Dw}^{-1}$ ) and higher contents at GARR and ROCH (about $8.2 \mathrm{mg} . \mathrm{g}^{\mathrm{DW}}$ ${ }^{1}$ ). The reader is referred to Appendix B for further detailed on spatio-temporal variability of biological factors.

\subsection{Statistical model}


Regarding model coefficients, the $b$ coefficient (related to $B_{\text {leaf }}$, Figure $3 a$ ) appears relatively constant for all tested hypothesis (about -0.27$)$ except for temperature $\left(T_{\text {mean }}\right)$ for which values are higher (about -0.2). Similar patterns were found for $C_{1}$ coefficient (related to $P A R_{\text {site }}$ ): values were generally close to 0.35 for most of the variables and were slightly lower $(0.32)$ for temperatures. Some variables had a negative impact on seagrass biomass (listed in a decreasing contribution order): temperature $\left(T_{\text {mean }}\right)$, vegetated area $\left(V_{\text {area }}\right.$, the percentage of area where seagrass were present), relative wave exposure index $\left(R E I_{75}\right)$, current velocity $\left(V_{75}\right)$, sediment organic matter content $\left(O M_{\text {sed }}\right)$ and sediment dry density $\left(\rho_{d r y}\right)$. Other variables had a positive impact on seagrass growth (listed in a decreasing contribution order): oceanic flushing time $\left(F_{\text {sea }}\right)$, impact of rivers $\left(F_{\text {riv }}\right)$, immersion time $\left(I_{\text {time }}\right)$, sediment median grain size $\left(D_{50}\right)$. Regarding the quality of model predictions on the basis of AICc and BIC (Figure 3b) and RMSE and MASE (Figure 3c) values, the best predictions were obtained using hydrological variables $\left(F_{\text {sea }}\right.$ and $\left.F_{r i v}\right)$ and hydrodynamics variables $\left(V_{75}\right.$ and $\left.R E I_{75}\right)$. For other tested variables, the predictions were not improved compared with the model using only local PARs (so-called None: no additional variable), and sorting obtained for variables was not always the same. 

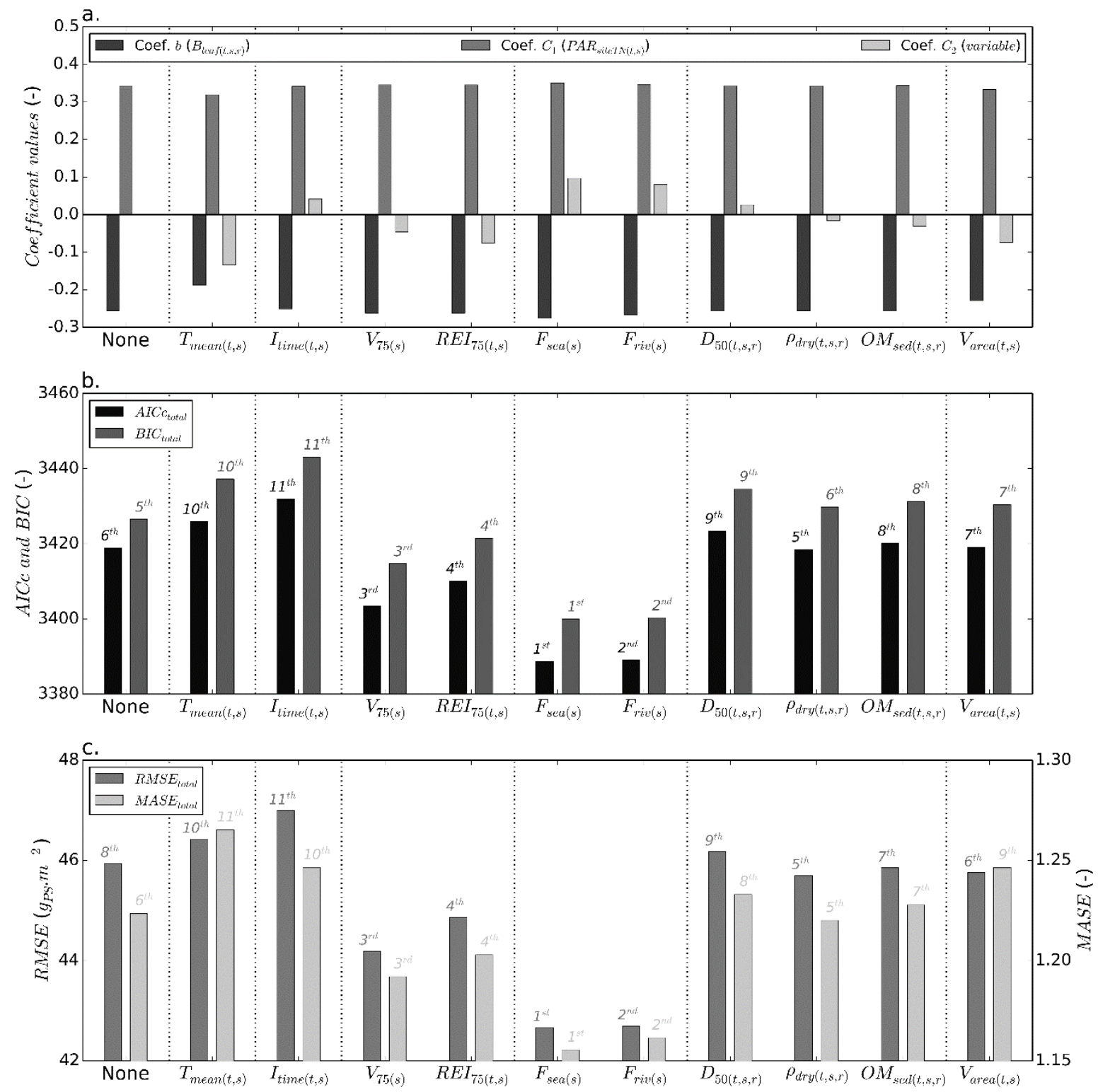

Figure 3: Model results for tested variables. (a.) values of the three model coefficients $\left(b, C_{l}\right.$, and $C_{2}$ ); (b.) AICc and BIC values (with modality rank); (c.) RMSE and MASE values (with modality rank).

(Figure 3 width: 2 columns)

The best predictors for each site highlighted different responses depending on site (Figure 4; see also Appendix $\mathrm{C}$ for the site by site ranking of each variable). First, for site GAIL, the best 
prediction was obtained using only local PARs indicating that none of the additional variables helped to improve model prediction (Figure 4f and Table 4). For three sites (ROCH, ILE and FONT) hydrological parameters $\left(F_{\text {sea }}\right.$ or $\left.F_{r i v}\right)$ increased prediction quality. For site JACQ, mean temperature $\left(T_{\text {mean }}\right)$ increased prediction quality, while the maximum of biomass was better predicted using oceanic flushing time $\left(F_{\text {sea }}\right.$, Figure $\left.4 \mathrm{~b}\right)$. At site PASS, the best prediction was provided by use of current velocity (Figure 4c). For site HAUT, the best prediction of maximum biomass was obtained using vegetated area, while the beginning of the growth period was better predicted using oceanic flushing time (Figure 4d). The low biomass measured over the year at site ANDE was well predicted using the sediment organic matter content (Figure 4h). Finally, GARR remained strongly underestimated, irrespective of the variable used (Figure 4a). 

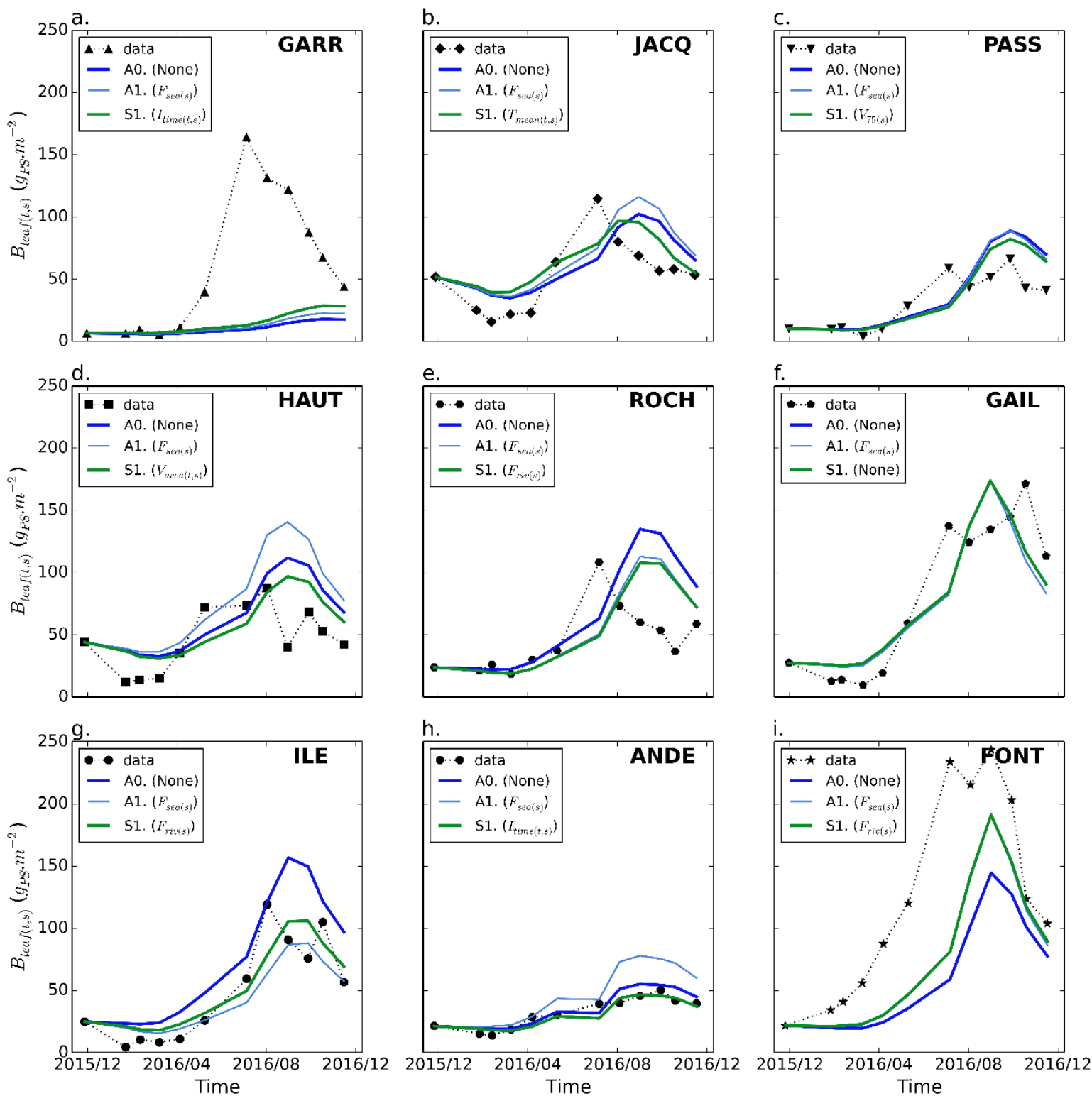

Figure 47: Comparison of measured and predicted leaf biomass. Measured (dark) and predicted biomass for each site: in dark blue (AO) the modality using light only, in light blue (A1) the best modality over all sites, in dark green (S1) the best modality for each site.

(Figure 4 width: 2 columns)

\section{DISCUSSION}


The seagrass $Z$. noltei is found in a wide range of intertidal and subtidal temperate systems characterized by a large spectrum of environmental conditions (den Hartog, 1970). As a result, the morphology and seasonal growth cycle of this seagrass can be highly variable (Cabaço, 2009; Vermaat, 1996, 2000). Our detailed monitoring of nine seagrass beds in Arcachon Bay over a year showed that the wide variability of seagrass responses to environmental conditions may also be observed at a local scale (see also Auby and Labourg 1996; Ganthy, 2011).

Regarding nitrogen and phosphorus leaf contents, we measured a similar seasonal cycle to that obtained by Plus (2001) in the Mediterranean Thau lagoon, with maximum in early spring and minimum in late summer. However, maximum values were two times higher than those found in this study, suggesting higher nutrient levels in Arcachon Bay. These high nitrogen concentrations within plants result both from freshwater inputs (mainly $\mathrm{NO}_{3}$ ) (Deborde et al., 2008) and organic matter remineralization $\left(\mathrm{NH}_{4}\right)$ (Bourgues et al., 1996) associated with important nitrogen fixation in seagrass beds performed by sulphate-reducing bacteria (Welsh et al., 1996). Duarte (1990) showed that seagrass growth can be limited by nitrogen and phosphorus when leaf contents are respectively lower than 20 and $2 \mathrm{mg} \cdot \mathrm{g} \mathrm{Dw}^{-1}$. Comparing these thresholds with our data indicates that only the site ILE could be temporarily limited in phosphorus during summer. Hence it is reasonable to conclude that Z. noltei are globally not limited by nutrients in Arcachon bay.

The range of chlorophyll content measured during this study is close to that measured in other environments and at different depths by Auby et al. (1999) or by Peralta et al. (2000). We found negative relationships between light effectively received by plants and total chlorophyll contents (Figure 5a) and, only for sites located below the mean sea level, between light and shoot length (Figure 5b). As previously shown these relationships reveal an adaptation mechanism to light conditions (Olesen et al., 2002; Peralta et al., 2002). As shown by de los 
Santos et al. (2010), hydrodynamics influence shoot height only for saturating light conditions (between 15.6 and 18.5 mol photons. $\mathrm{m}^{-2}$. day $^{-1}$ depending on environments; Peralta et al., 2002 ; Plus et al., 2005). This could explain the gradation of mean shoot length for sites not included in the regression (Figure 5b) and receiving large amounts of light, for which shoot lengths are negatively correlated with currents and waves (Figure 2).

Previous studies highlighted the main control of light on Z. noltei growth and distribution (Duarte, 1991; Peralta et al., 2000). However, the light effectively received by seagrasses is a multi-dependent parameter: it depends first on surface light irradiance, which depends on latitude, on season, on hour of the day and on weather; it also depends on both local depth and water turbidity (controlled by suspended sediments, phytoplankton, macroalgae...). This large to small scale complexity requires precise and high frequency measurements of local light to adequately take it into account within a statistical model. As previously indicated (see also Appendix C), the use of site-specific light received by plants provided better model predictions compared to the regional irradiance and even to site-dependant temperatures. However, the predicted biomass in the deepest (GARR, Figure 4a) and the shallowest (FONT, Figure 4i) sites were strongly underestimated by the model.

For the deepest site (GARR), the model strongly underestimates the biomass, tending to confirm the positive role of adaptation mechanism to low light conditions. For the shallowest site (FONT), another explanation may be proposed: we observed that this seagrass bed, located in a shallow tidal pool, was always covered by a thin water layer even at low tide (Figure 5c), avoiding desiccation and allowing it to maintain high photosynthesis rates during low tides (Shafer, 2007). 

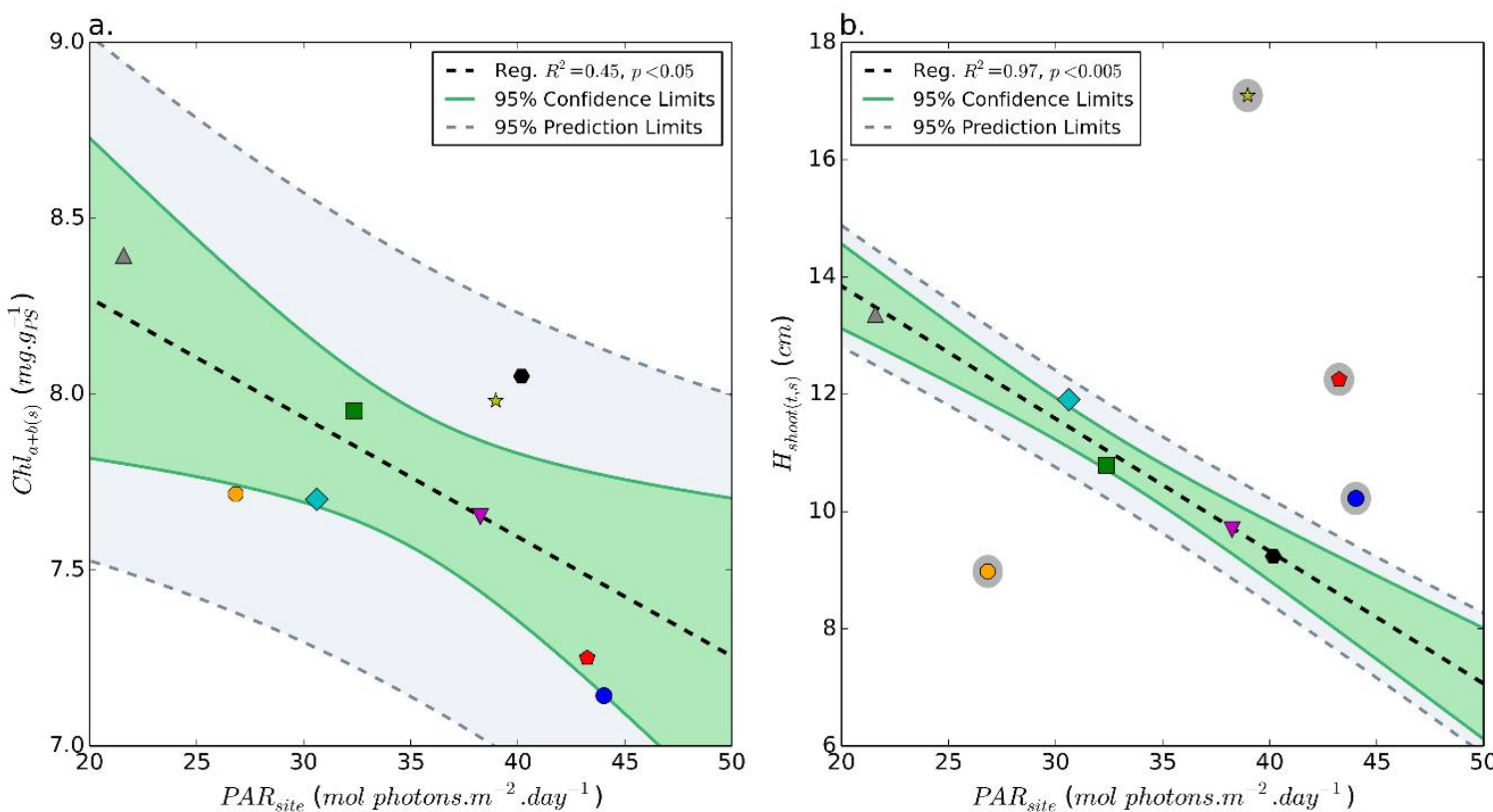

\begin{tabular}{|llllllll}
\hline$\triangle$ GARR & JACQ & $\nabla$ PASS & 口 HAUT & $-\mathrm{ROCH}$ & $\bullet \mathrm{GAIL}$ & $\bullet \mathrm{ILE}$ & ANDE \\
\hline
\end{tabular}

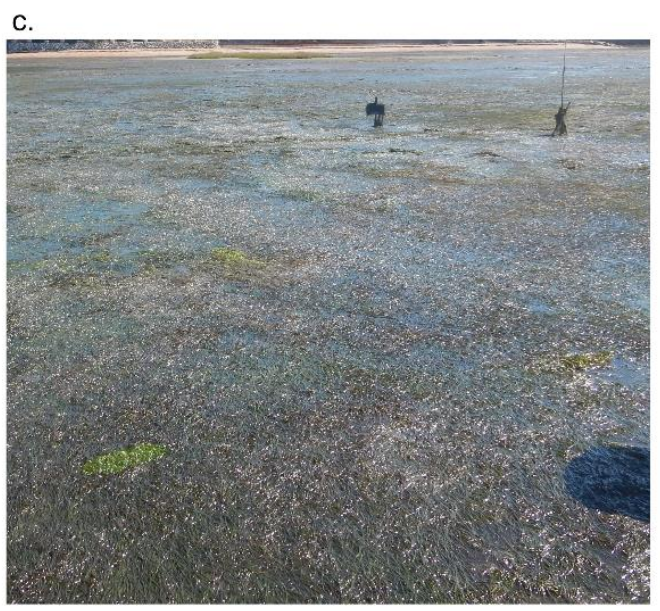

d.

Figure 5: (a.) Relationship between light received by plants on each site $\left(P A R_{\text {site }}\right)$ and total chlorophyll content $\left(C h l_{a+b}\right) ;(b$.$) relationship between light received by plants on each site$ $\left(P A R_{\text {site }}\right)$ and shoot length $\left(H_{\text {shoot }}\right)$ for sites located below the mean sea level (sites located above mean sea level have a grey circle); (c.) photograph of site FONT in mid-summer highlighting that seagrasses are covered by water (about $10 \mathrm{~cm}$ ) even at low tide; (d.) photograph of site ANDE in mid-summer showing important algal mat.

(Figure 5 width: 1.5 column) 
Adding one of the two hydrological variables $\left(F_{\text {sea }}\right.$ or $\left.F_{r i v}\right)$ as a second model variable generally improved biomass prediction reliability, through a positive impact on seagrass biomass (positive sign of $C_{2}$ coefficient, Figure 3a). These two variables reflect both nutrients and potential contaminant inputs from rivers, and provide an indicator of exposure time for seagrass beds. Herbicide concentrations in the rivers were measured during the survey by the REPAR network (https://www.siba-bassin-arcachon.fr/actions-environnementales/lesreseaux-de-surveillance-repar-et-rempar/repar). The positive effect of hydrological variables on biomass suggests that herbicide supply was not high enough to reduce seagrass biomass, or that beneficial effect of nutrients supply was higher than the negative effect of contaminant inputs.

Furthermore, hydrodynamic variables $\left(R E I_{75}\right.$ and $\left.V_{75}\right)$ also improved the accuracy of model prediction through a negative impact on seagrass biomass (Figure 3). The direct effects of hydrodynamics on seagrasses has been well-described (Balke et al., 2014; Fonseca \& Bell, 1998; Koch, 2001). Nevertheless, significant negative correlations were found between hydrological and hydrodynamics, since the area of highest flushing times are those of the lowest currents and lowest wave exposure $\left(p<0.02\right.$ for $R E I_{75}$ versus $F_{\text {sea }}$ or $F_{\text {riv }}$ and $p<0.05$ for $U V_{75}$ versus $F_{\text {sea }}$ or $F_{\text {riv }}$ ). This implies that hydrodynamics contribution was included within hydrological variables, due to their co-linearity. The relationships between flushing times and current velocities may be attributed to the general morphology of the Bay. Indeed, the western sites were close to the main channels, where current velocities are the highest, while eastern sites were mostly surrounded by tidal flats and tidal creeks where velocities are lower. Moreover, despite eastern sites characterized by longer fetch for dominant winds (SW to NW winds), they appeared more sheltered from wind-waves (Parisot et al., 2008; Pedreros et al., 2008). This may be explained by higher bottom friction in eastern parts induced both by 
shallower depth even at high tide and by the presence of large seagrass beds (Paul and Amos, 2011).

The sites PASS and GAILL did not appear to be controlled by other environmental factors than light. Indeed, the use of a site-specific variable within the model contributed to a very low increase in prediction quality compared to the model using only light (Figure 4, Appendix C). The biomass prediction at site ILE was substantially improved using the impact of rivers $\left(F_{r i v}\right)$ instead of oceanic flushing time $\left(F_{\text {sea }}\right)$. This site was the most oceanic and the least impacted by rivers considered as nutrient inputs; this supports the hypothesis that western seagrass beds (such as ILE) could sometimes be limited by nutrients as previously mentioned. The fact that immersion time $\left(I_{\text {time }}\right)$ appears to be the main controlling factor for site GARR, even if this site is poorly predicted probably due to adaptation mechanism to low light conditions (Figure 5a, Appendix C) tends to confirm the importance of depth. Finally, for site ANDE, a very low value of light was measured during July; this may certainly be related to the important amount of opportunistic macroalgae observed on the field (Figure 5d). Furthermore, this site had very high sediment organic matter content (Table1; Appendix B), which may be due to the degradation of these macroalgae. Two different processes related to the presence of algal mats could explain the very low biomass measured at this site. Firstly, these mats may drastically reduce the quantity of light reaching plants; secondly, anaerobic degradation of these mats may lead to sulfide production which is toxic for Z. noltei (Govers et al., 2014).

Zostera (Z. marina and Z. noltei) beds in Arcachon Bay have shown a strong stability of their extent and health between 1950s and 1990s, as related by fishermen and by available scientific reports (e.g. Lubet, 1956; Auby and Labourg, 1996). In the middle of 2000s, the 
seagrass decline in Arcachon Bay started, initially through regression of Z. marina in eastern parts of the Bay, then affecting Z. noltei beds mainly in lower parts of tidal flats formerly lined by Z. marina (Cognat, unpublished data; Plus et al., 2010).

Understanding the mechanisms controlling Zostera noltei growth in the current state of the ecosystem is required to better apprehend the reasons preventing seagrass recovery following its abrupt decline. Due to the multiplicity of factors affecting seagrass growth, it appeared essential to compile a comprehensive dataset, including most physical and biological processes, to unravel the local effects of various drivers on seagrass seasonal growth. The approach coupling high frequency field survey of numerous environmental and biological variables, as well as results from hydrodynamic simulations provided such a comprehensive dataset. The use of a logistic growth model allowed us to sort relative contributions of environmental factors from local (site) and regional (Arcachon bay) scales, which provided insight for possible management actions for restoration of Z. noltei in the bay.

Our results showed that beyond light, hydrodynamics mostly controlled seagrass growth at the scale of the bay. This suggested that within the expected positive feedback loop between hydrodynamics (i.e. increased currents and waves), sediment dynamics (i.e. increased erosion and light reduction) and intertidal seagrass beds, the effects of light reduction were secondary compared with the effects of erosion (i.e. local scouring and mechanical wrenching) due to seagrass capacity to acclimate to low light conditions. Furthermore, at a local scale, other factors such as macroalgal mats or micro-topography (presence of tidal pools) also significantly influenced Z. noltei growth. In terms of management, these results suggest that better sites for eventual intertidal Z. notlei transplantations of plant or seeds would not necessarily be the less turbid ones but preferably the most sheltered from hydrodynamics. To prevent hydrodynamic stress and disturbance, the habitat could be locally stabilized using shells or stones for example (van Katwijk et al., 2009) or by reducing current and/or wave 
energy using artificial structures. Furthermore, it seems useful to take advantage of micro topography and set these transplants in tidal pools to avoid desiccation at low tide.

Finally, this method can be transposed provide guidance for local management in other regions. Its application to various regions all over the world, where Zostera beds occur at different stages of decline, may provide further insight about general causes of world decline. Furthermore, once the statistical model is built and its robustness is checked, one of the possible applications could be the simulation of scenarios, in order to investigate and possibly quantify seagrass responses to change in environmental factors, either individually or in combination changing factors. This appears to be a valuable tool to evaluate management actions or predict effects of climate change. 


\section{Nomenclature}

\begin{tabular}{|c|c|c|c|}
\hline Group & Variable & Description & Unit \\
\hline \multirow{23}{*}{ Data } & $B_{\text {leaft }(t, s, r)}$ & Aboveground biomass & $\mathrm{g}$ Dw $\cdot \mathrm{m}^{-2}$ \\
\hline & $B_{\text {root }(t, s, r)}$ & Underground biomass & $\mathrm{g}_{\mathrm{DW}} \cdot \mathrm{m}^{-2}$ \\
\hline & $C_{\text {leaft } t, s)}$ & Leaf carbon content & $\%$ \\
\hline & $C h l_{a(t, s, r)}$ & Leaf chlorophyll-a content & mg. $g_{\text {DW }}{ }^{-1}$ \\
\hline & $C h l_{b(t, s, r)}$ & Leaf chlorophyll-b content & mg. $g_{D W}{ }^{-1}$ \\
\hline & $C h l_{a+b(t, s, r)}$ & Leaf chlorophyll-a+b content & mg. $g_{D W}{ }^{-1}$ \\
\hline & $\operatorname{Cov}_{(t, s)}$ & Leaf cover in the vegetated area & $\%$ \\
\hline & $D_{50(t, s, r)}$ & Median grain size (bed sediments) & $\mathrm{mm}$ \\
\hline & $D_{\text {shoot }(t, s, r)}$ & Shoot density & $\mathrm{m}^{-2}$ \\
\hline & $F_{r i v(s)}$ & Local river flushing time & day \\
\hline & $F_{\text {sea }(s)}$ & Local oceanic flushing time & day \\
\hline & $H_{\text {shoot }(t, s, r)}$ & Shoot height & $\mathrm{m}$ \\
\hline & $I r_{O(t)}$ & Daily irradiance (in air) & $\mathrm{J}^{\mathrm{c} . \mathrm{cm}^{-2}} \cdot \mathrm{day}^{-1}$ \\
\hline & $I_{\text {time}(t, s)}$ & Immersion time & hour.day ${ }^{-1}$ \\
\hline & $N_{\text {leaff } t, s)}$ & Leaf nitrogen content & $\%$ \\
\hline & $O M_{\text {sed }(t, s, r)}$ & Bed sediments organic matter content & $\%$ \\
\hline & $P A R_{\text {site }(t, s)}$ & Local light intensity & mol.m ${ }^{-2} \cdot$ day $^{-1}$ \\
\hline & $P_{\text {leaf(t,s) }}$ & Leaf phosphorus content & $\%$ \\
\hline & $R E I_{(t, s)}$ & Relative Wave Exposure Index & - \\
\hline & $T_{\text {mean }(t, s)}$ & Local temperature & ${ }^{\circ} \mathrm{C}$ \\
\hline & $V_{\text {areal }(t, s)}$ & Vegetated area on a site & $\%$ \\
\hline & $V_{75(t, s)}$ & $75^{\text {th }}$ percentile of near-bed velocities & $\mathrm{m} . \mathrm{s}^{-1}$ \\
\hline & $r_{d r y(t, s, r)}$ & Bed sediments dry bulk density & kg. $\mathrm{m}^{-3}$ \\
\hline \multirow{7}{*}{$\begin{array}{c}\text { Statistical } \\
\text { Model }\end{array}$} & $b$ & Statisctical model $-r / K$ & - \\
\hline & $C_{1}$ & $\begin{array}{l}\text { Statistical model - coefficient for the first environmental } \\
\text { variable }\end{array}$ & - \\
\hline & $C_{2}$ & $\begin{array}{l}\text { Statistical model coefficient for the second environmental } \\
\text { variable }\end{array}$ & - \\
\hline & $K$ & Statistical model - maximal possible biomass & - \\
\hline & $r$ & Statistical model - maximum growth rate & - \\
\hline & $r_{0}$ & Statistical model - site independant growth rate & - \\
\hline & $y_{t}$ & Statisctical model - relative growth rate & - \\
\hline \multirow{4}{*}{ Metrics } & $A I C c$ & Corrected Akaike information criterion & - \\
\hline & $B I C$ & Corrected Bayesian information criterion & - \\
\hline & MASE & Mean absolute error & - \\
\hline & RMSE & Root mean squared error & $\mathrm{g}_{\mathrm{DW}} \cdot \mathrm{m}^{-2}$ \\
\hline
\end{tabular}




\section{Acknowledgements}

This work was part of the French project ZODARSED, funded by the French National Research Agency (ANR) in the frame of the Investment for the future Program, within the Cluster of Excellence COTE (ANR-10-LABX-45) and Ifremer (the French Institute for Research and Sea Exploitation). We would particularly like to thank Ifremer for its technical and instrumental support, as well as all the staff of the Ifremer Arcachon laboratory (technicians, engineers and researchers) who volunteered their time and assistance during the field experiments. The scientific support from M. Marzloff, M. Plus and R. Verney (IfremerDYNECO) was particularly appreciated for both the definition of sampling strategy and the data treatment. Finally we would like to thank A. Esdaile, as well as the two referees for their constructive comments and corrections which helped us to improve the structure, style and wording of our manuscript. 


\section{Appendix A. Detailed protocol for measurements of environmental and}

\section{biological parameters}

\section{A.1 Light and temperature}

At each site, local light intensity (lumens. $\mathrm{m}^{-2}$ ) and temperature $\left({ }^{\circ} \mathrm{C}\right)$ were measured continuously at high frequency (10 minutes sampling rate) using HOBO ${ }^{\circledR}$ Pendant ${ }^{\circ}$ UA-00264 data loggers fixed (at $0.05 \mathrm{~m}$ above the bed) on aluminium sticks inserted into the seabed. The HOBO UA-002-64 sensors are planar light sensors designed to measure light intensity in a range of wavelength from 150 to $1200 \mathrm{~nm}$. Prior to and after their deployment at each site, all the sensors were fixed together on an aluminium plate and deployed during 5 days on a tidal flat. Maximum differences in light intensity were below $5 \%$, while temperatures differences were below $1 \%$, which confirms the consistency between the sensors and allows a reliable comparison of the measurements obtained at different sites during the survey. Moreover, since the HOBO $\odot$ sensors measure visible light levels in lumens by square meter instead of photosynthetically active radiation (PAR) in micromoles per square meter per second a LiCor@ LI-193 underwater spherical quantum sensor of PAR was also placed on the field during two short deployments. Comparison of light measurements by the HOBOC loggers to those obtained with the LiCor@ sensor in air and in water presented significant linear relationships $(P A R=c \times$ Light $)$ both for measurements, with respectively $c=0.0263$ $(p<0.01)$ and $c=0.0482(p<0.001)$. Instantaneous light received at each sensor during the whole survey was first converted in PAR using obtained sensor-dependent coefficients, depending on whether the sensor were emerged or submerged (see next section for water depth measurements). The mean daily PAR received by plants along each survey period $\left(P A R_{\text {site }}\right.$, mol photons. $\mathrm{m}^{-2}$.day $\left.{ }^{-1}\right)$ was then calculated as the sum of instantaneous measures 
multiplied by the measurement time-step, and normalized by the number of days between two site inspections. Temperatures were averaged along each survey period $\left(T_{\text {mean }}\right)$.

\section{A.2 Water level and wave exposure index}

Water level fluctuations due to tides were recorded using absolute pressure gauges (HOBOßU20L, precision: $1 \mathrm{~cm}$, resolution: $0.21 \mathrm{~cm}$ ), placed at about $10 \mathrm{~cm}$ above the sea floor on aluminium sticks half-buried in the bed. The pressure signal was recorded every 10 minutes and was corrected from variation of atmospheric pressure using hourly data (linearly interpolated) from the Météo-France weather station. These measurements of water levels allowed the computation of averaged immersion times by days $\left(I_{\text {time }}\right.$, hour.day $\left.{ }^{-1}\right)$.

In order to assess the potential impact of wind-waves on seagrass, a modification of the Relative Wave Exposure Index (REI) described in Robbins et al., (2001) was performed. First the instantaneous REI $(\operatorname{REI}(t, s))$ was computed based on water level measurements (recorded every 10 minutes), combined with wind direction and velocity $\left(V_{\text {wind }(t, s)}, \mathrm{m} . \mathrm{s}^{-1}\right)$ provided by the Météo-France weather station. As wind is recorded every 3 hours, data was linearly interpolated to generate samples synchronous with water level measurements. A bathymetric map (soundings performed in years $2015-2016$ by the Service Maritime de Navigation de la Gironde) interpolated using an anisotropic kriging, on a grid with a resolution of $25 \mathrm{~m}$, was also used. For each water level sample, effective fetch $\left(F_{\text {eff }}(t, s), \mathrm{m}\right)$ was computed as the distance between the site and the last grid cell containing water along the transect corresponding to the instantaneous wind direction. When instantaneous water depth at the site was less than $0.1 \mathrm{~m}$, the site was considered as emerged and $F_{\text {eff }}(t, s)$ was set to 0 . The water depth along the fetch transect was averaged using an inverse distance function from the site to the last immerged point of the transect, giving $h_{i d w}(t)(\mathrm{m})$. Then, instantaneous REI was 
computed as: $\operatorname{REI}(t)=F_{\text {eff }}(t)$. $h_{i d w}(t)$. $V_{\text {wind }}(t)$. Finally, for each survey period (duration between two site inspections) we computed the $75^{\text {th }}$ percentile of instantaneous REI, giving $R E I_{75}$

\section{A.3 Bed sediment properties}

At each sampling time (i.e. every month during low tide), the uppermost $5 \mathrm{~cm}$ of bed sediments were collected using small cores (diameter of $3 \mathrm{~cm}$ ) to determine various sediment parameters. Three replicates were collected within different seagrass patches showing the highest leaf cover (visually estimated) of the site.

First, the bulk dry density ( $\rho_{d r y}$, in $\mathrm{kg} \cdot \mathrm{m}^{-3}$ ) was measured using the method fully described in Ganthy et al. (2015) after homogenization of the sample.

Second, the rest of sampled sediments were placed into larger pill boxes (volume $25 \mathrm{~cm}^{3}$ ) after homogenization for grain size analysis and organic matter content determination. Grain size analyses were performed using a Malvern laser particle sizer that measures a size range from 0.02 to $2000 \mu \mathrm{m}$. To prevent obstruction of the Malvern device, samples were first sieved $(2000 \mu \mathrm{m})$ to remove fragments of shells and seagrasses. Median grain size $\left(D_{50}, \mathrm{~mm}\right)$ was obtained directly from outputs of the Malvern device. For organic matter determination, samples were also sieved $(2000 \mu \mathrm{m})$ and placed on ceramic crucibles. They were dried $\left(70{ }^{\circ} \mathrm{C}\right.$ for 15 days), weighed $\left(M_{o m, d r y}\right.$, in $\left.\mathrm{kg}\right)$ and then burned at $450{ }^{\circ} \mathrm{C}$ for 4 hours. After cooling in a desiccator, samples were re-weighed $\left(M_{a s h}\right.$, in $\left.\mathrm{kg}\right)$. Finally, organic matter content $\left(O M_{\text {sed }}\right.$, in $\%)$ was calculated as $O M_{\text {sed }}=100\left(M_{o m, d r y}-M_{a s h}\right) / M_{o m, d r y}$.

\section{A.4 Seagrass biometry}


For seagrass biometry, 3 cores samples (100 mm diameter and $100 \mathrm{~mm}$ in length) of seagrass were collected within the three different seagrass patches exhibiting the highest leaf cover of the site as for sediment samples. This implies an assumed bias which can be considered to be relatively constant between sites and time (i.e. overestimation of biomass compared with the totality of the site).

Back in the laboratory, the plant samples were gently washed and rubbed with freshwater on a sieve (mesh size $1.5 \mathrm{~mm}$ ) to separate seagrasses from sediment and shell fragments, and to remove a maximum of epiphytes from seagrass leaves. The seagrasses were then frozen until biometric analysis. For this analysis, seagrasses were first separated into above- and belowground parts. When the rhizomes and roots were soft and dark brown, they were considered to be dead and were therefore not weighed. The number of shoots per sample was counted, providing the shoot density $\left(D_{\text {shoot}}\right.$, in $\left.\mathrm{m}^{-2}\right)$. The length of the longest leaf was measured for ten randomly selected shoots to obtain the mean shoot height $\left(H_{\text {shoot }}\right.$, in $\left.\mathrm{m}\right)$. The aboveground (leaves + sheaths) and underground (rhizomes + roots) biomasses ( $B_{\text {leaf }}$ and $B_{\text {root }}$ respectively, in $\mathrm{g} \cdot \mathrm{m}^{-2}$ ) were calculated after drying at $60{ }^{\circ} \mathrm{C}$ for about $72 \mathrm{~h}$.

\section{A.5 Seagrass chlorophyll and nutrient contents}

To avoid oversampling within the site, seagrass leaves used for these measurements were randomly collected 10 meters around the site area. Samples were pooled and transported to the laboratory. The leaves were gently rinsed and scraped in order to remove epiphytes. Afterwards they were frozen and dried in a freeze dryer.

For each sample, chlorophyll extraction was performed by grinding three replicates of leaves with $90 \%$ acetone in a mortar kept in the dark and in ice blocks to prevent chlorophyll destruction. The extracts were centrifuged (at $1500 \mathrm{rpm}$ for $5 \mathrm{~min}$ ) and the pigment content 
was assayed from the supernatant using absorption spectrophotometry (using a UnicamUV Series). The equations from Jeffrey and Humphrey (1975) were used to quantify chlorophyll-a $\left(C h l_{a}, \mathrm{mg} \cdot \mathrm{g}_{\mathrm{DW}}{ }^{-1}\right)$ and chlorophyll-b $\left(C h l_{b}, \mathrm{mg} \cdot \mathrm{g}_{\mathrm{DW}}{ }^{-1}\right)$ contents.

Carbon $\left(C_{\text {leaf }}, \%\right)$ and nitrogen $\left(N_{\text {leaf }}, \%\right)$ contents were measured using a $\mathrm{CN}$ analyzer Elementar Vario MAX CUBE. Phosphorus content $\left(P_{\text {leaf }}, \%\right)$ was determined using the ICPAES Agilent 725 spectrometer after extraction with concentrated $\mathrm{HNO}_{3}$ of previously burned $\left(5 \mathrm{~h}\right.$ at $\left.480{ }^{\circ} \mathrm{C}\right) 1 \mathrm{~g}$ plant samples. 


\section{Appendix B. Spatio-temporal variability of environmental and biological}

\section{factors}

Table B.1 The results ( $F$ and $p$ values) obtained from one- or two-way ANOVAs performed for each environmental parameters.

\begin{tabular}{|c|c|c|c|c|}
\hline \multirow{2}{*}{$\begin{array}{c}\text { Source of variation / } \\
\text { Variable }\end{array}$} & \multicolumn{2}{|c|}{ Site variation $(\mathrm{df}=8)$} & \multicolumn{2}{|c|}{ Time variation $(\mathrm{df}=10)$} \\
\hline & $\mathrm{F}$ & $\mathrm{p}$ & $\mathrm{F}$ & $\mathrm{p}$ \\
\hline$I r_{O(t)}$ & - & - & (+inf) & $<0.001$ \\
\hline$T_{\text {mean }(t, s)}$ & (+inf) & $<0.001$ & (+inf) & $<0.001$ \\
\hline$P A R_{\text {site }(t, s)}$ & (+inf) & $<0.001$ & (+inf) & $<0.001$ \\
\hline$R E I_{75(t, s)}$ & (+inf) & $<0.001$ & (+inf) & $<0.001$ \\
\hline$D_{50(t, s, r)}$ & 71.021 & $<0.001$ & 1.803 & 0.062 \\
\hline$\rho_{d r y(t, s, r)}$ & 69.888 & $<0.001$ & 0.863 & 0.568 \\
\hline$O M_{\text {sed }(t, s, r)}$ & 109.655 & $<0.001$ & 1.834 & 0.057 \\
\hline$B_{\text {leaf }(t, s, r)}$ & 59.644 & $<0.001$ & 66.042 & $<0.001$ \\
\hline$B_{\text {root }(t, s, r)}$ & 22.913 & $<0.001$ & 10.593 & $<0.001$ \\
\hline$D_{\text {shoot }(t, s, r)}$ & 12.728 & $<0.001$ & 51.437 & $<0.001$ \\
\hline$H_{\text {shoot }(t, s, r)}$ & 93.253 & $<0.001$ & 137.094 & $<0.001$ \\
\hline$V_{\text {area }(t, s)}$ & (+inf) & $<0.001$ & (+inf) & $<0.001$ \\
\hline $\operatorname{Cov}_{(t, s)}$ & $(+$ inf) & $<0.001$ & (+inf) & $<0.001$ \\
\hline$N_{\text {leaf }(t, s)}$ & (+inf) & $<0.001$ & (+inf) & $<0.001$ \\
\hline$P_{\text {leaf }(t, s)}$ & (+inf) & $<0.001$ & (+inf) & $<0.001$ \\
\hline$C h l_{\alpha(t, s, r)}$ & 13.171 & $<0.001$ & 18.523 & $<0.001$ \\
\hline$C h l_{\beta(t, s, r)}$ & 3.053 & $<0.005$ & 17.029 & $<0.001$ \\
\hline$C h I_{\alpha+\beta(t, s, r)}$ & 5.307 & $<0.001$ & 15.207 & $<0.001$ \\
\hline
\end{tabular}




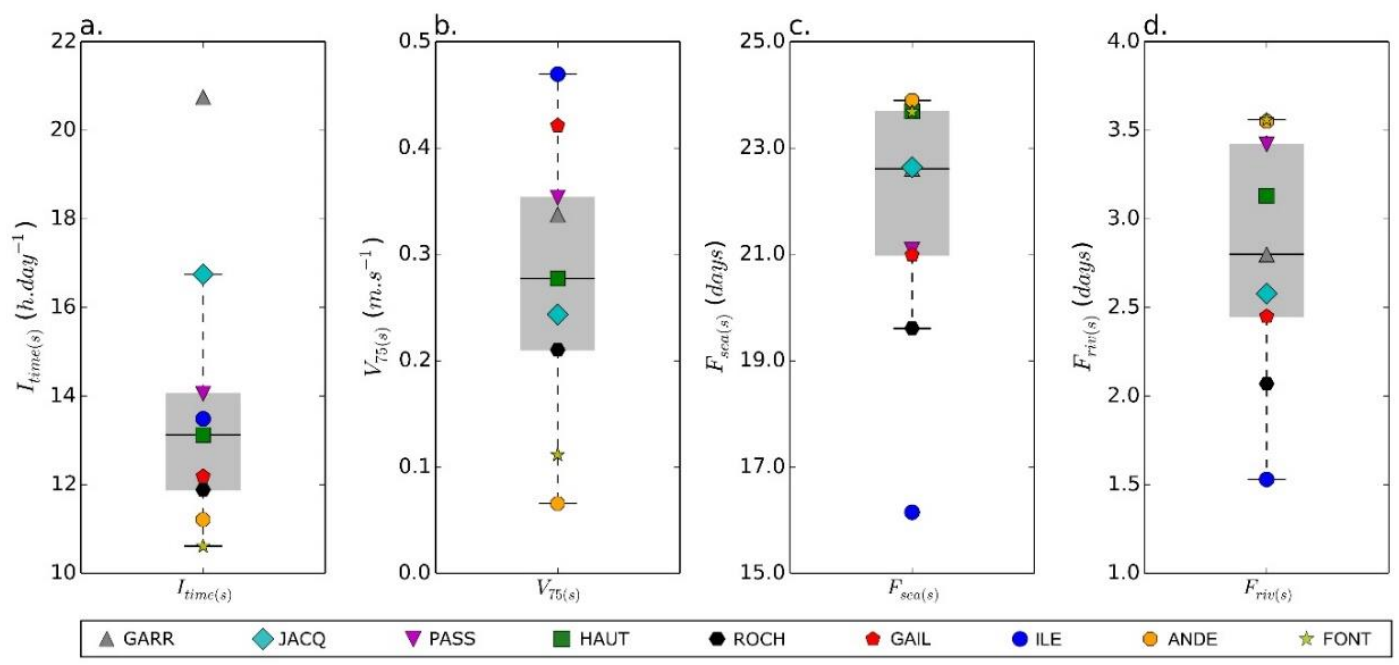

Figure B.1: Spatial variability of main environmental factors. (a.) time-averaged immersion time; (b.) current velocity; (c.) oceanic flushing time; (d.) impact of rivers for each site.

Symbols are the values for each site. The box extends from the $1^{\text {st }}$ to $3^{\text {rd }}$ percentiles (innerquartile), with a line at the median. The whiskers extend to the most extreme data points included in the interval 1.5 innerquartile range (non-outlier data points).

(Figure B.1 width: 2 columns; color online only) 


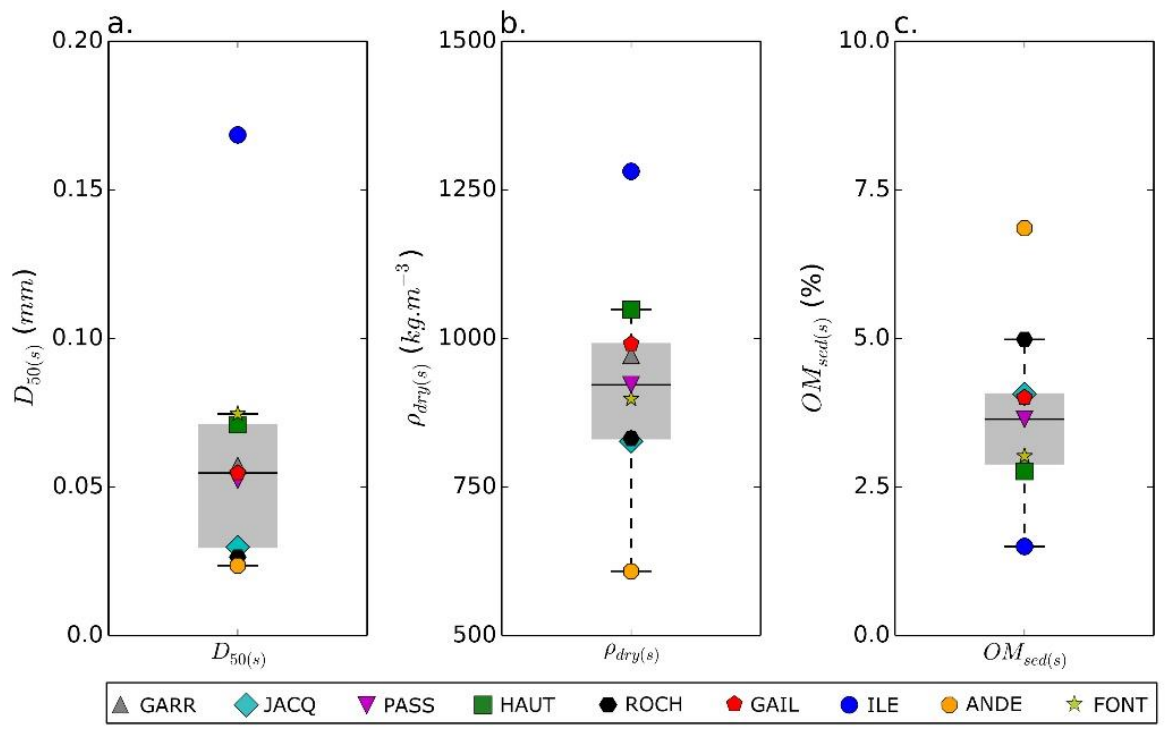

Figure B.2: Spatial variability of main bed sediment characteristics. (a.) median grain size;

(b.) dry density; (c.) organic matter content for each site. Symbols are the values for each site.

The box extends from the $1^{\text {st }}$ to $3^{\text {rd }}$ percentiles (innerquartile), with a line at the median. The whiskers extend to the most extreme data points included in the interval 1.5 innerquartile range (non-outlier data points).

(Figure B.2 width: 1.5 column, color online only) 

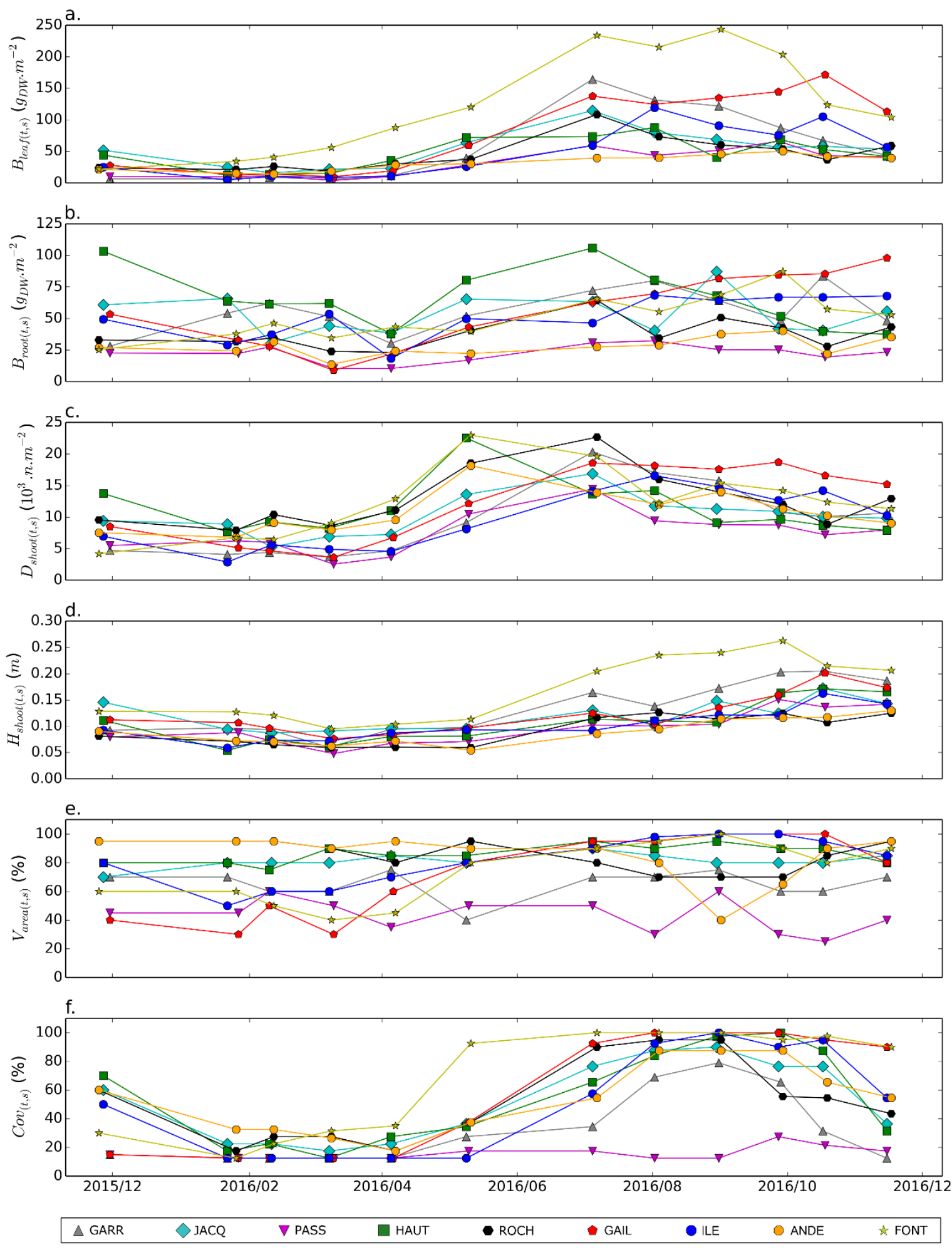

Figure B.3: Time series of main biological parameters. (a.) aboveground biomass; (b.) belowground biomass; (c.) shoot density; (d.) shoot height; (e.) vegetated area; (f.) leaf coverage at each site. 
(Figure B.3 width: 2 columns, color online only) 

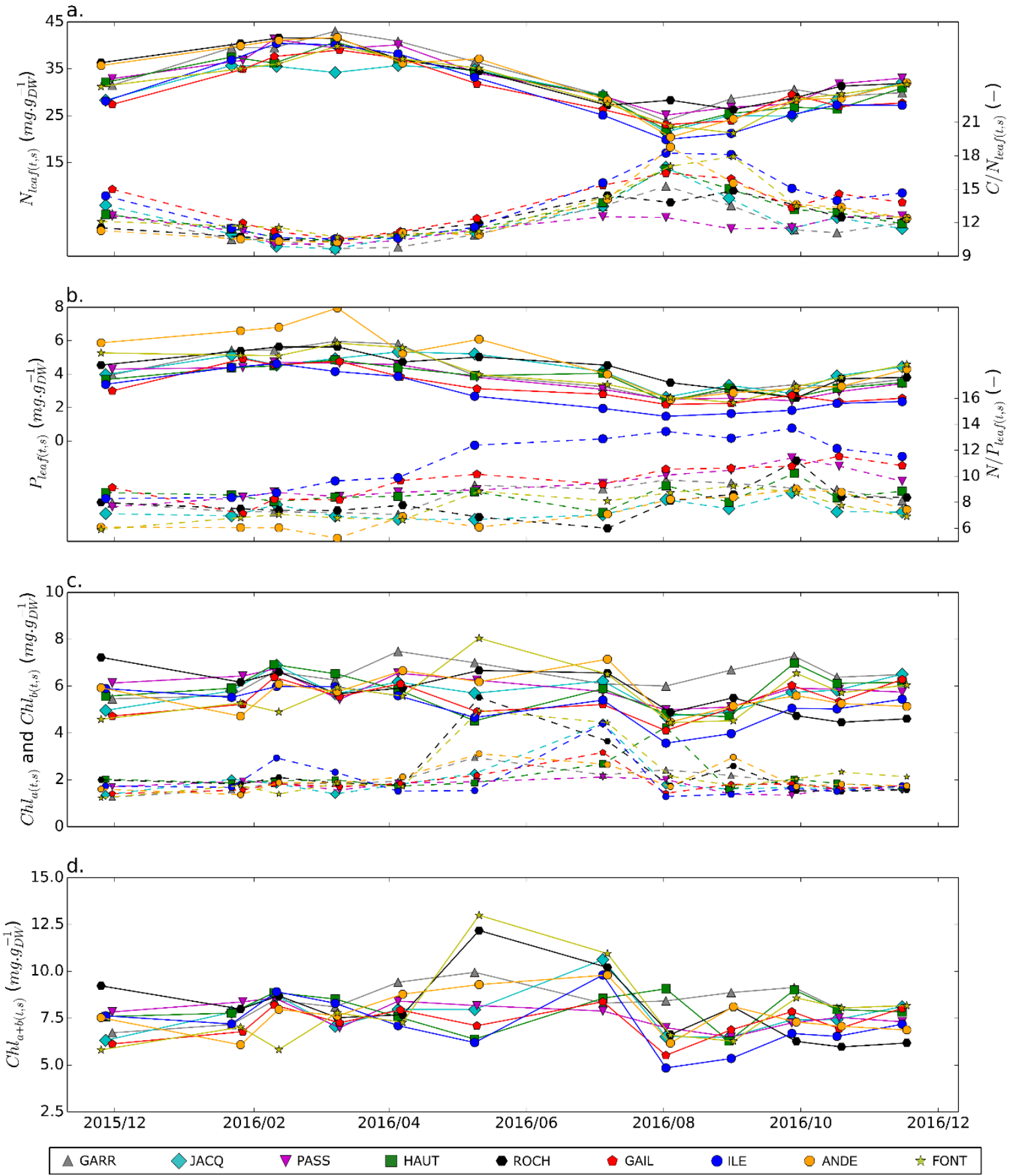

Figure B.4: Time-series of nutrient and chlorophyll contents. Leaf content of (a.) nitrogen (solid line) and nitrogen over carbon ratio (dashed line); (b.) phosphorus (solid line) and phosphorus over nitrogen ratio (dashed line); (c.) chlorophyll a (solid lines) and chlorophyll b (dashed lines); (d.) total chlorophyll $(a+b)$. 
(Figure B.4 width: 2 columns)

\section{Appendix C. Additional statistical model results}

Table C.1 The metrics for estimation on statistical model reliability depending on first tested variable (effective light received by each site $-P A R_{\text {site, }}$, irradiance received at Météo France weather station - $I r_{0}$, and mean temperature measured at each site, $\left.T_{\text {mean }}\right)$.

\begin{tabular}{|c|c|c|c|c|}
\hline Metrics / Variable & $\mathrm{AIC}_{\mathrm{c}}$ & BIC & RMSE & MASE \\
\hline$P A R_{\text {site }(t, s)}$ & 3419 & 3427 & 45.9 & 1.2 \\
\hline$I_{0(t)}$ & 3439 & 3446 & 47.8 & 1.3 \\
\hline$T_{\text {mean }(t, s)}$ & 3469 & 3476 & 50.6 & 1.3 \\
\hline
\end{tabular}


a.

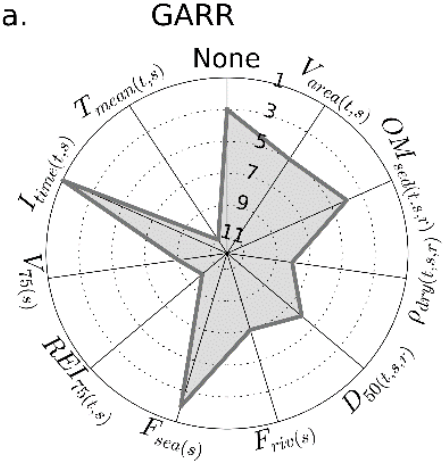

d.

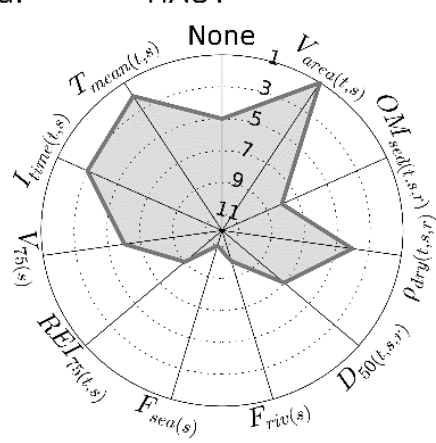

g. ILE

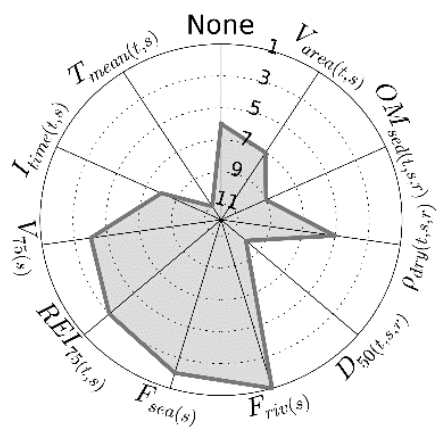

b. $\mathrm{ACQ}$

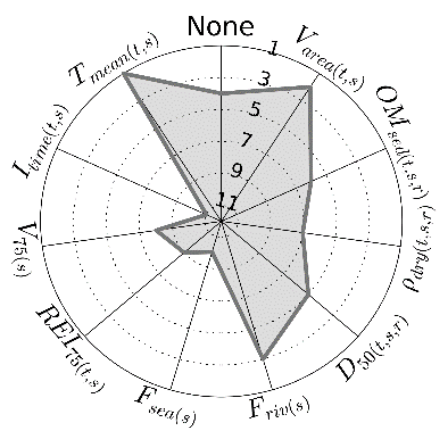

e. $\mathrm{ROCH}$

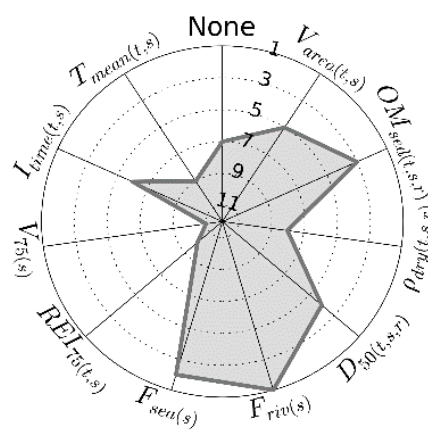

h.

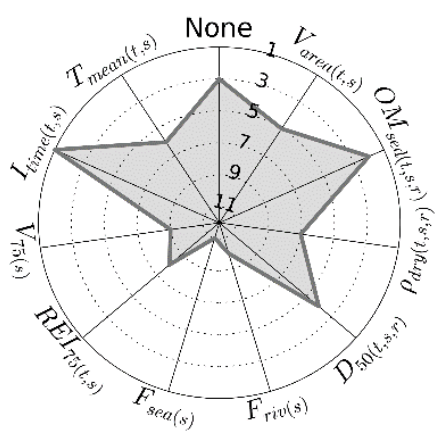

c. PASS

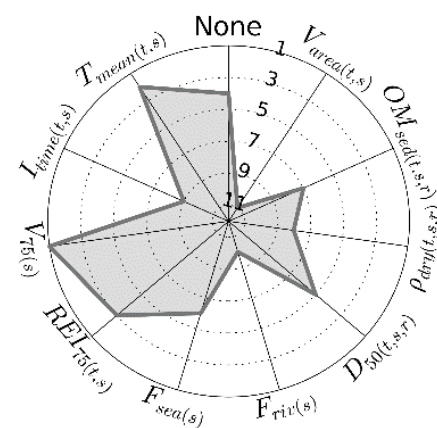

f. GAIL

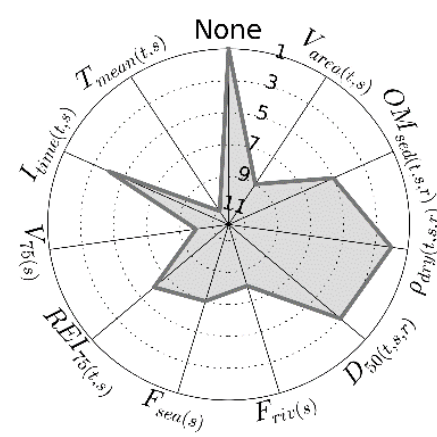

i. $\quad$ FONT

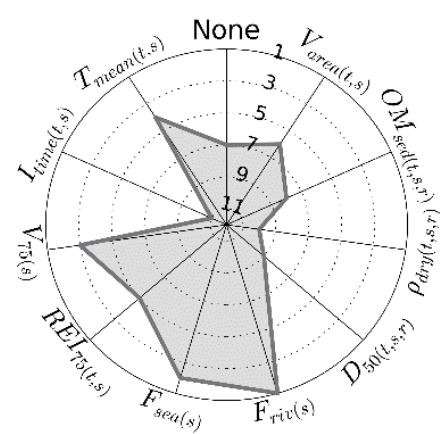

Figure C.1 Radars plots showing the relative rank of each secondary variable tested within the statistical model. "None" indicates the model integrating only the light, without secondary variable. 
Table C.2 The metrics used to quantify the statistical model reliability for each site, and providing best biomass predictions. "A0" corresponds to the model without secondary variable (only light included within the model); "A1" corresponds to the model integrating a secondary variable and providing the best regional prediction (best prediction over all sites); "S1" corresponds to the model integrating a secondary variable and providing the best local prediction (best prediction site by site).

\begin{tabular}{|c|c|c|c|c|c|c|c|c|c|c|}
\hline \multirow{2}{*}{ Parameter } & \multirow{2}{*}{ Model } & \multicolumn{9}{|c|}{ Sites } \\
\hline & & GARR & JACQ & PASS & HAUT & $\mathrm{ROCH}$ & GAIL & ILE & ANDE & FONT \\
\hline \multirow{3}{*}{ Variable } & $\mathrm{A} 0$ & \multicolumn{9}{|c|}{ only $P A R_{\text {site(s) }}$} \\
\hline & $\mathrm{A} 1$ & \multicolumn{9}{|c|}{$F_{\text {sea }(s)}$} \\
\hline & $\mathrm{S} 1$ & $I_{\text {time }(t, s)}$ & $T_{\text {mean }(t, s)}$ & $V_{75(s)}$ & $V_{\text {area }(t, s)}$ & $F_{r i v(s)}$ & None & $F_{r i v(s)}$ & $I_{\text {time }(t, s, r)}$ & $F_{r i v(s)}$ \\
\hline \multirow{3}{*}{ RMSE } & A0 & 75.551 & 26.217 & 21.320 & 31.831 & 43.834 & 31.768 & 35.742 & 9.098 & 82.712 \\
\hline & A1 & 73.815 & 29.675 & 20.771 & 43.436 & 35.372 & 33.476 & 21.949 & 20.206 & 66.886 \\
\hline & $\mathrm{S} 1$ & 71.649 & 21.891 & 18.582 & 26.995 & 34.151 & 31.768 & 20.173 & 7.913 & 66.483 \\
\hline \multirow{3}{*}{ MASE } & A0 & 1.535 & 1.126 & 1.171 & 1.300 & 1.547 & 0.768 & 1.133 & 1.115 & 1.469 \\
\hline & $\mathrm{A} 1$ & 1.474 & 1.290 & 1.146 & 1.683 & 1.235 & 0.505 & 0.637 & 2.381 & 1.135 \\
\hline & $\mathrm{S} 1$ & 1.395 & 0.921 & 1.016 & 1.126 & 1.195 & 0.768 & 0.653 & 0.924 & 1.118 \\
\hline \multirow{3}{*}{$\mathrm{R}^{2}$} & A0 & 0.230 & 0.415 & 0.672 & 0.314 & 0.246 & 0.748 & 0.778 & 0.723 & 0.617 \\
\hline & A1 & 0.222 & 0.422 & 0.676 & 0.349 & 0.229 & 0.723 & 0.754 & 0.679 & 0.684 \\
\hline & $\mathrm{S} 1$ & 0.219 & 0.622 & 0.670 & 0.294 & 0.225 & 0.748 & 0.765 & 0.734 & 0.679 \\
\hline
\end{tabular}




\section{References}

Aho, K., Derryberry, D., Peterson, T. (2014). Model selection for ecologists: the worldviews of AIC and BIC. Ecology 95(3):631-636

Auby I. and Labourg P.-J. (1996). Seasonal dynamics of Zostera noltii Hornem. in the Bay of Arcachon. J Sea Res

35(4):269-277

Auby I., Levavasseur G., Plus M., Deslous Paoli J.M., Grillas P. (1999). Comparaison des capacités photosynthétiques des zostères naines de deux étangs méditerranéens : Lagune de Thau et étang du Vaccarès. Colloque "Le milieu aquatique : interactions des facteurs environnementaux et impacts sur les organismes vivants". Brest, 30 septembre - 1 octobre 1999. http://archimer.ifremer.fr/doc/00152/26287/

Auby I. and Maurer D. (2004). Etude de la reproduction de l'huître creuse dans le Bassin d'Arcachon. Rapport final. Rapport Ifremer R.INT.DEL/AR/04.05, 203

Auby I., Bocquené G., Quiniou F., Dreno J.P. (2007). Etat de la contamination du Bassin d'Arcachon par les insecticides et les herbicides sur la période 2005-2006. Impact environnemental RST/LER/AR/07.003, 33 pp.

Auby I., Bost C.-A., Budzinski H., Dalloyau S., Desternes A., Belles A., Trut G., Plus M., Pere C., Couzi L., Feigne C., Steinmetz J. (2011). Régression des herbiers de zostères dans le Bassin d'Arcachon : état des lieux et recherche des causes. RST/ODE/LER/AR/11.007. http://archimer.ifremer.fr/doc/00054/16507/

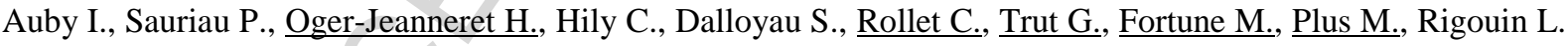
(2014). Protocoles de suivi stationnel des herbiers à zostères pour la Directive Cadre sur l'Eau (DCE) Zostera marina - Zostera noltei. Version 2. RST/LER/AR/14.01

Balke T., Herman P.M.J., Bouma T.J. (2014). Critical transitions in disturbance-driven ecosystems: identifying windows of opportunity for recovery. J Ecol 102:700-708

Bourgues S., Auby I., de Wit R., Labourg, P. J. (1996). Differential anaerobic decomposition of seagrass (Zostera noltii) and macroalgal (Monostroma obscurum) biomass from Arcachon Bay (France). In Coastal Lagoon Eutrophication and ANaerobic Processes (CLE AN.) pp. 121-131. Springer, Dordrecht.

Bos A.R., Bouma T.J., de Kort G.L.J., van Katwijk M.M. (2007). Ecosystem engineering by annual intertidal seagrass beds: sediment accretion and modification. Estuar Coast Shelf Sci 74:344-348 
Brun F.G., Vergara J.J., Navarro G., Hernández I., Pérez-Lloréns J.L. (2003). Effect of shading by Ulva rigida canopies on growth and carbon balance of the seagrass Zostera noltii. Mar Ecol Prog Ser 265: 85-96

Burkholder J.A.M., Mason K.M., Glasgow H.B. (1992). Water-column nitrate enrichment promotes decline of eelgrass Zostera marina: evidence from seasonal mesocosm experiments. Mar Ecol Prog Ser 81:163-178

Cabaço S., Machás R., Santos R. (2009). Individual and population plasticity of the seagrass Zostera noltii along a vertical intertidal gradient. Estuar Coast Shelf Sci 82(2):301-308

Carr J., D’Odorico P., McGlathery K., Wiberg P. (2010). Stability and bistability of seagrass ecosystems in shallow coastal lagoons: role of feedbacks with sediment resuspension and light attenuation. J Geophys Res 115:G03011

Carrère L., Lyard F., Cancet M., Guillot A., Roblou L. (2013). FES2012: A new global tidal model taking advantage of nearly twenty years of altimetry. 20 Years of Progress in Radar Altimetry Symposium (Venice Italy) 1-20, 2013

Castel J., Caumette P., Herbert R. (1996). Eutrophication gradients in coastal lagoons as exemplified by the Bassin d'Arcachon and the Etang du Prévost. Hydrobiologia 329:ix-xxv111.

Chesworth J.C., Donkin M.E., Brown M.T. (2004). The interactive effects of the antifouling herbicides Irgarol 1051 and Diuron on the seagrass Zostera marina. Aquat Toxicol 66:293-305

Costanza R., d’Arge R., de Groot R., Farber S., Grasso M., Hannon B., Limburg K., Naem S., O’Neil R.V., Paruelo J., Raskin R.G., Sutton P., van den Belt M. (1997). The value of the world's ecosystem services and natural capital. Nature 387:253-260

Deborde J., Anschutz P., Auby I., Glé C., Commarieu M.-V., Maurer D., Lecroart P., Abril G. (2008). Role of tidal pumping on nutrient cycling in a temperate lagoon (Arcachon Bay, France). Mar. Chem 109:98-114.

Den Hartog. C. (1970). The sea-grasses of the world. Verh. kon. ned. Akad. Wet., Afd. Natuurkunde, 59(1):275

Dormann C.F., Elith J., Bacher S., Buchmann C., Carl G., Carré G., García Marquéz J.R., Gruber B., Lafourcade B., Leitão P.J., Münkemüller T., McClean C., Osborne P.E., Reineking B., Schröder B., Skidmore A.K., Zurell D., Lautenbach S. (2013). Collinearity: a review of methods to deal with it and a simulation study evaluating their performance. Ecography 36:027-046

Duarte C. M. (1990). Seagrass nutrient content. Mar Ecol Prog Ser 201-207

Duarte C.M. (1991). Seagrass depth limits. Aquat Bot 40:363-377 
Duffy J.E. (2006). Biodiversity and the functioning of seagrass ecosystems. Mar Ecol Prog Ser 311:233-250

Fauvelle V. (2012). Evaluation de la contamination en pesticides des tributaires du bassin d'Arcachon et développement d'un échantillonneur passif spécifique des herbicides anioniques. $\mathrm{PhD}$ Thesis Université Bordeaux $259 \mathrm{pp}$

Fernández-Torquemada Y. and Sánchez-Lizaso J.L. (2011). Response of two Mediterranean seagrasses to experimental changes in salinity. Hydrobiologia 669:21-33

Fonseca M.S. and Bell S.S. (1998). Influence of physical setting on seagrass landscapes near Beaufort, North Carolina, USA. Mar Ecol Prog Ser 171:109-121

Gamain P., Feurtet-Mazel A., Maury-Brachet R., Auby I., Pierron F., Belles A., Budzinski H., Gonzalez P. (2017). Can pesticides, copper and seasonal water temperature explain the seagrass Zostera noltei decline in the Arcachon bay?. Mar Pollut Bull. IN PRESS

Ganthy F. (2011). Rôle des herbiers de zostères (Zostera noltii) sur la dynamique sédimentaire du Bassin d'Arcachon. PhD Thesis, Université Bordeaux 1, 282 pp.

Ganthy F., Sottolichio A., Verney R. (2013). Seasonal modification of tidal flat sediment dynamics by seagrass meadows of Zostera noltii (Bassin d'Arcachon, France). J Mar Syst 109-110:S233-S240

Ganthy F., Soissons L., Sauriau P.G., Verney R., Sottolichio A. (2015). Effects of flexible seagrass Zostera noltei on flow, erosion and deposition processes determined using flume experiments. Sedimentology 62:997-1023

Gao Y., Fang J., Zhang J., Ren L., Mao Y., Li B., Zhang M., Liu D., Du M. (2011). The impact of the herbicide atrazine on growth and photosynthesis of seagrass, Zostera marina (L.), seedlings. Marine pollution bulletin $62(8): 1628-1631$

Govers L. L., de Brouwer J. H., Suykerbuyk W., Bouma T. J., Lamers L. P., Smolders A. J., van Katwijk M. M. (2014). Toxic effects of increased sediment nutrient and organic matter loading on the seagrass Zostera noltii. Aquat toxicol 155:253-260

Graham M.H. (2003). Confronting multicollinearity in ecological multiple regression. Ecology 84(11):28092815. 
van der Heide T., van Nes E.H., Geerling G.W., Smolders A.J.P., Bouma T.J., van Katwijk M.M. (2007). Positive feedbacks in seagrass ecosystems: implications for success in conservation and restoration. Ecosystems 10:1311-1322

Hyndman R.J. and Koehler A.B. (2006). Another look at measures of forecast accuracy. Int J Forecast 22:679688

Ifremer (2017). Bulletin de la Surveillance de la Qualité du Milieu Marin Littoral 2016. Résultats acquis jusqu'en 2016. Ifremer/ODE/LITTORAL/LERAR/17.004, 55p. http://envlit.ifremer.fr/content/download/83308/602948/file/Bull_2017_AR.pdf

Jeffrey S.W., Humphrey G.F. (1975). New spectrophotometric equations for determining chlorophylls a, b, c1 and c2 in higher plants, algae and natural phytoplankton. Biochem Physiol Pflanzen 167:191-194

van Katwijk M.M., Bos A.R., de Jonge V.N., Hansen L.S.A.M., de Jong D.J. (2009). Guidelines for seagrass restoration: Importance of habitat selection and donor populations, spreading risks, and ecosystem engineering effects. Mar. Pollut. Bull 58:179-188.

Koch E.W. (2001) Beyond light: physical, geological, and geochemical parameters as possible submersed aquatic vegetation habitat requirements. Estuaries 24:1-17

Koch E.W., Ackerman J.D., Verduin J.J, van Keulen M. (2006). Fluid dynamics in seagrass ecology - from molecules to ecosystems. In: Larkum A.W.D., Orth R.J., Duarte C.M. (eds) Seagrasses: biology, ecology and conservation. Springer Dordrecht, p. 193-225.

Kombiadou K., Ganthy F., Verney R., Plus M., Sottolichio A. (2014). Modelling the effects of Zostera noltei meadows on sediment dynamics : application to the Arcachon lagoon. Ocean Dyn 64:1499-1516

Koutitonsky V.G., Guyondet T., St-Hilaire A., Courtenay S.C., Bohgen A. (2004). Water renewal estimates for aquaculture developments in the Richibuto estuary, Canada. Estuaries 27:839-850

Lazure P. and Dumas F. (2008). An internal-internal mode coupling for a 3D hydrodynamical model for application at regional scale (MARS). Adv in Water Resour 31:233-250

Leuschner C., Landwehr S., Mehlig U. (1998). Limitation of carbon assimilation of intertidal Zostera noltii and Zostera marina by desiccation at low tide. Aquat Bot 62:171-176

Lubet P. (1956). Considération écologiques sur les herbiers du Bassin d'Arcachon. P.V. Soc. Lin. Bordeaux 96:95-103 
Massa S.I., Arnaud-Haond S., Pearson G.A., Serrão E.A. (2009.) Temperature tolerance and survival of intertidal populations of the seagrass Zostera noltii (Hornemann) in Southern Europ (Ria Formossa, Portugal). Hydrobiologia 619:195-201

McGlathery K.J. (2001). Macroalgal blooms contribute to the decline of seagrass in nutrient-enriched coastal waters. J Phycol 37:453-456

Nielsen L.W. and Dahllöf I. (2007). Direct and indirect effects of the herbicides glyphosate, bentazone and MCPA on eelgrass (Zostera marina). Aquat Toxicol 82:47-54

Ochieng C.A., Short F.T., Walker D.I. (2010). Photosynthetic and morphological response of eelgrass (Zostera marina L.) to a gradient of light conditions. J Exp Mar Biol Ecol 382:117-124

Olesen B., Enríquez S., Duarte C.M., Sand-Jensen K. (2002). Depth-acclimation of photosynthesis, morphology and demography of Posidonia oceanica and Cymodocea nodosa in the Spanish Mediterranean Sea. Mar Ecol Prog Ser 236:89-97

Orth R.J., Carruthers T.J.B., Dennison W.C., Duarte C.M., Fourqurean J.W., Heck K.L., Hughes A.R., Kendrick G.A., Kenworthy W.J., Olyarnik S., Short F.T., Waycott M., Williams S.L. (2006). A global crisis for seagrass ecosystems. Bioscience 56:987-996

Orth R.J., Williams M.R., Marion S.R., Wilcox D.J., Carruthers T.J.B., Moore K.A., Kemp W.M., Denison W.C., Rybicki N., Bergstrom P., Batiuk R.A. (2010). Long-term trends in submersed aquatic vegetation (SAV) in Chesapeake Bay, USA, related to water quality. Estuar Coasts 33:1144-1163

Paine C.E.T., Marthews T.R., Vogt D.R., Purves D., Rees M., Hector A., Turnbull L.A. (2012). How to fit nonlinear plant growth models and calculate growth rates: an update for ecologists. Methods Ecol Evol 3:245-256

Parisot J.P., Diet-Davancens J., Sottolichio A., Crosland E., Drillon C., Verney R. (2008). Modélisation des agitations dans le Bassin d'Arcachon. Proceeding Xèmes Journées Nationales Génie Côtier - Génie Civil, 14-16 octobre 2008, Sophia Antipolis (France).

Paul M. and Amos C.L. (2011). Spatial and seasonal variation in wave attenuation over Zostera noltii. J Geophys Res 116:C08019 
Peralta G., Pérez-Lloréns J.L., Hernández I., Brun F., Vergara J.J., Bartual A., Gálvez J.A., García C.M. (2000). Morphological and physiological differences between two morphotypes of Zostera noltii Hornem. from the south-western Iberian Peninsula. Helgol Mar Res 54:80-86

Peralta G, Pérenz-Lloréns JL, Hernández I, Vergara JJ (2002) Effects of light availability on growth, architecture and nutrient content of the seagrass Zostera noltii Hornem. J Exp Mar Biol Ecol 269:9-26

Pedreros R., Lecacheux S., Sottolichio A., Romieu E., Idier D., Salles P., Delattre M. (2008) Caractérisation des vagues dans les passes du bassin d'Arcachon. Proceedings Xèmes Journées Nationales Génie Côtier Génie Civil, 14-16 octobre 2008, Sophia Antipolis (France) (pp. 273-282)

Plus M., Deslous-Paoli J., Auby I., Dagault F. (2001). Factors influencing primary production of seagrass beds (Zostera noltii Hornem.) in the Thau lagoon (French Mediterranean coast). J Exp Mar Biol Ecol 259:63-84

Plus M., Auby I., Verlaque M., Levavaseur G. (2005). Seasonal variations in photosynthetic irradiance response curves of macrophytes from a Mediterranean lagoon. Aquat Bot 81:157-173

Plus M., Dumas F., Stanisière J.Y., Maurer D. (2009). Hydrodynamic characterization of the Arcachon Bay, using model-derived descriptors. Cont Shelf Res 29:1008-1013

Plus M., Dalloyau S., Trut G., Auby I., de Montaudouin X., Emery E., Noël C., Viala C. (2010). Long-term evolution (1988-2008) of Zostera spp. meadows in Arcachon Bay (Bay of Biscay). Estur Coast Shel Sci $87: 357-366$

Robbins B.D., Fonseca M.S., Whitfield P.E., Clinton P. (2001). Use of a wave exposure technique for predicting distribution and ecological characteristics of seagrass ecosystems. In Proceedings: Seagrass management: It's not just nutrients, October 6, 2000. H.S. Greening, ed, 171-176 Tampa Bay National Estuarine Program, St. Petersburg, FL.

de los Santos C.B., Brun F.G., Bouma T.J., Vergara J.J., Pérez-Lloréns J.L. (2010). Acclimation of seagrass Zostera noltii to co-occuring hydrodynamic and light stress. Mar Ecol Prog Ser 398:127-135

Shafer D.J., Sherman T.D., Wyllie-Echeverria S. (2007). Do desiccation tolerance control the vertical distribution of intertidal seagrasses? Aquat Bot 87:161-166

Short F.T. (1987). Effects of sediment nutrients on seagrasses: literature review and mesocosm experiment. Aquat Bot 27:41-57 
Soissons L.M., van Katwijk M.M., Peralta G., Brun F.G., Cardoso P.G., Grilo T.F., Ondiviela B., Recio M., Valle M., Garmendia J.M., Ganthy F., Auby I., Rigouin L., Godet L., Fournier J., Desroy N., Barillé L., Kadel P., Asmus R., Herman P.M.J., Bouma T.J. (2018). Seasonal and latitudinal variation in seagrass mechanical traits across Europe: The influence of local nutrient status and morphometric plasticity. Limnol. Oceanogr 63(1):37-46.

Suykerbuyk W., Govers L., Bouma T.J., Giesen W.B.J.T., de Jong D.J., van de Voort R., Giesen K., Giesen P.T., van Katwijk M.M. (2016). Unpredictability in seagrass restoration: analysing the role of positive feedback and environmental stress on Zostera noltii transplants. J Appl Ecol 53:774-784

Vermaat, J.E.,Verhagen, F.C.A. (1996). Seasonal variation in the intertidal seagrass Zostera noltii Hornem.: coupling demographic and physiological patterns. Aquat Bot. 52:259-281

Vermaat J.E., Verhagen F.C.A., Lindenburg D. (2000). Contrasting response in two populations of Zostera noltii Hornem. to experimental photoperiod manipulation at two salinities. Aquat Bot 67:179-189

Waycott M., Procaccini G., Les D. H., Reusch T. B. (2007). Seagrass evolution, ecology and conservation: a genetic perspective. In Seagrasses: biology, ecology and conservation 25-50. Springer Netherlands

Welsh D.T., Bourguès S., de Wit R., R.A. Herbert. Seasonal variations in nitrogen-fixation (acetylene reduction) and sulphate-reduction rates in the rhizosphere of Zostera noltii: nitrogen fixation by sulphate-reducing bacteria. Mar. Biol 125:619-628

Winddows J., Pope N.D., Brinsley M.D., Asmus H., Asmus R.M. (2008). Effects of seagrass beds (Zostera noltii and Zostera marina) on near-bed hydrodynamics and sediment dynamics. 358:125-136 
Table 1: The spatial variability of environmental and biological parameters for each site (constant parameter or yearly-averaged \pm standard deviation).

\begin{tabular}{|c|c|c|c|c|c|c|c|c|c|}
\hline Site/Parameter & GARR & JACQ & PASS & HAUT & ROCH & GAIL & ILE & ANDE & FONT \\
\hline $\operatorname{Hwat}_{\max }(m)$ & 3.44 & 2.94 & 2.67 & 2.35 & 2.32 & 2.27 & 2.22 & 2.20 & 2.09 \\
\hline$I_{\text {time }}\left(\right.$ hour.day $\left.{ }^{-1}\right)$ & 20.7 & 16.7 & 14.1 & 13.1 & 11.9 & 12.2 & 13.5 & 11.2 & 10.6 \\
\hline$V_{75}\left(m \cdot s^{-1}\right)$ & 0.34 & 0.24 & 0.35 & 0.28 & 0.21 & 0.42 & 0.47 & 0.07 & 0.11 \\
\hline$F_{\text {sea }}($ days $)$ & 22.6 & 22.6 & 21.1 & 23.7 & 19.6 & 21.0 & 16.1 & 23.9 & 23.7 \\
\hline$F_{r i v}($ days $)$ & 2.8 & 2.6 & 3.4 & 3.1 & 2.1 & 2.4 & 1.5 & 3.6 & 3.6 \\
\hline$R E I_{75}(-)$ & $2.31 \pm 0.34$ & $2.16 \pm 0.98$ & $2.79 \pm 0.41$ & $2.07 \pm 0.80$ & $1.69 \pm 0.72$ & $2.82 \pm 0.77$ & $4.08 \pm 1.64$ & $1.05 \pm 0.45$ & $1.14 \pm 0.60$ \\
\hline$T_{\text {mean }}\left({ }^{\circ} \mathrm{C}\right)$ & $\begin{array}{c}16.31 \pm \\
4.98\end{array}$ & $\begin{array}{c}16.32 \pm \\
5.03\end{array}$ & $\begin{array}{c}16.42 \pm \\
5.14\end{array}$ & $\begin{array}{c}16.37 \pm \\
5.11\end{array}$ & $\begin{array}{c}16.33 \pm \\
5.15\end{array}$ & $\begin{array}{c}16.28 \pm \\
5.04\end{array}$ & $\begin{array}{c}16.55 \pm \\
4.87\end{array}$ & $\begin{array}{c}13.31 \pm \\
5.21\end{array}$ & $\begin{array}{c}16.00 \pm \\
5.31\end{array}$ \\
\hline$D_{50}(\mu m)$ & $57.2 \pm 0.22$ & $29.8 \pm 6.4$ & $52.3 \pm 20.1$ & $71.0 \pm 22.6$ & $26.5 \pm 19.1$ & $54.7 \pm 27.9$ & $\begin{array}{c}168.6 \pm \\
50.3\end{array}$ & $23.5 \pm 4.1$ & $74.7 \pm 65.0$ \\
\hline$\rho_{d r y}(k g . m-3)$ & $966 \pm 80$ & $831 \pm 74$ & $908 \pm 175$ & $1054 \pm 104$ & $833 \pm 128$ & $980 \pm 189$ & $1306 \pm 81$ & $611 \pm 114$ & $900 \pm 30$ \\
\hline$O M_{\text {sed }}(\%)$ & $2.90 \pm 0.58$ & $4.07 \pm 0.45$ & $3.64 \pm 1.06$ & $2.76 \pm 0.75$ & $4.99 \pm 0.91$ & $4.00 \pm 1.32$ & $1.50 \pm 0.55$ & $6.86 \pm 1.14$ & $3.02 \pm 0.54$ \\
\hline$V_{\text {area }}(\%)$ & $65 \pm 10$ & $81 \pm 5$ & $43 \pm 12$ & $86 \pm 6$ & $85 \pm 11$ & $72 \pm 28$ & $81 \pm 17$ & $85 \pm 16$ & $73 \pm 21$ \\
\hline $\operatorname{Cov}(\%)$ & $32 \pm 24$ & $52 \pm 18$ & $15 \pm 9$ & $54 \pm 23$ & $52 \pm 25$ & $57 \pm 40$ & $50 \pm 32$ & $53 \pm 18$ & $67 \pm 28$ \\
\hline$B_{\text {leaf }}\left(g_{D W \cdot} \cdot m^{-2}\right)$ & $57.8 \pm 62$ & $52.7 \pm 31.2$ & $31.4 \pm 22.4$ & $46.4 \pm 27.8$ & $45.6 \pm 29.9$ & $80.7 \pm 63.9$ & $49.3 \pm 41.6$ & $32.0 \pm 15.4$ & $\begin{array}{c}123.7 \pm \\
84.8\end{array}$ \\
\hline$B_{\text {root }}\left(g D W . m^{-2}\right)$ & $56.2 \pm 26.8$ & $52.8 \pm 20.9$ & $22.2 \pm 8.9$ & $66.0 \pm 25.2$ & $37.4 \pm 18.6$ & $55.8 \pm 30.7$ & $51.5 \pm 19.0$ & $27.8 \pm 13.2$ & $51.1 \pm 26.8$ \\
\hline $\begin{array}{l}D_{\text {shoot }}\left(10^{3}\right. \\
\left.\text { shoot. } m^{-2}\right)\end{array}$ & $9.60 \pm 5.65$ & $\begin{array}{c}10.17 \pm \\
3.85 \\
\end{array}$ & $7.58 \pm 3.37$ & $\begin{array}{c}11.31 \pm \\
4.69 \\
\end{array}$ & $\begin{array}{c}12.70 \pm \\
5.44\end{array}$ & $\begin{array}{c}12.14 \pm \\
6.47 \\
\end{array}$ & $9.63 \pm 4.87$ & $\begin{array}{c}10.79 \pm \\
3.93 \\
\end{array}$ & $\begin{array}{c}12.28 \pm \\
5.83 \\
\end{array}$ \\
\hline$H_{\text {shoot }}(m)$ & $0.13 \pm 0.05$ & $0.12 \pm 0.03$ & $0.10 \pm 0.03$ & $0.11 \pm 0.04$ & $0.09 \pm 0.03$ & $0.12 \pm 0.04$ & $0.10 \pm 0.03$ & $0.09 \pm 0.03$ & $0.17 \pm 0.06$ \\
\hline$C_{\text {leaf }}\left(m g \cdot g_{D W}^{-1}\right)$ & $\begin{array}{c}385.5 \pm \\
29.2\end{array}$ & $\begin{array}{c}362.6 \pm \\
30.3 \\
\end{array}$ & $\begin{array}{c}380.3 \pm \\
42.3 \\
\end{array}$ & $\begin{array}{c}389.0 \pm \\
26.3 \\
\end{array}$ & $\begin{array}{c}407.7 \pm \\
17.6 \\
\end{array}$ & $\begin{array}{c}400.6 \pm \\
14.7 \\
\end{array}$ & $\begin{array}{c}397.8 \pm \\
20.1 \\
\end{array}$ & $\begin{array}{c}400.9 \pm \\
16.2 \\
\end{array}$ & $\begin{array}{c}396.6 \pm \\
14.2 \\
\end{array}$ \\
\hline$N_{\text {leaf }}\left(m g \cdot g_{D W}^{-1}\right)$ & $33.5 \pm 5.9$ & $30.5 \pm 4.8$ & $33.2 \pm 5.2$ & $31.6 \pm 5.6$ & $33.8 \pm 5.4$ & $30.5 \pm 5.4$ & $30.2 \pm 7.0$ & $32.8 \pm 6.7$ & $31.3 \pm 5.5$ \\
\hline$P_{\text {leaf }}\left(m g \cdot g_{D W}{ }^{-1}\right)$ & $4.1 \pm 1.2$ & $4.2 \pm 0.9$ & $3.6 \pm 0.9$ & $3.7 \pm 0.8$ & $4.3 \pm 1.0$ & $3.3 \pm 1.0$ & $2.9 \pm 1.1$ & $4.9 \pm 1.7$ & $4.2 \pm 1.2$ \\
\hline$C h l_{a}\left(m g \cdot g_{D W}{ }^{-1}\right)$ & $6.44 \pm 0.75$ & $5.75 \pm 0.82$ & $5.91 \pm 0.69$ & $5.83 \pm 9.2$ & $5.75 \pm 1.08$ & $5.71 \pm 0.77$ & $5.17 \pm 0.92$ & $5.67 \pm 0.96$ & $5.67 \pm 1.12$ \\
\hline$C h l_{b}\left(m g \cdot g_{D W}{ }^{-1}\right)$ & $1.95 \pm 0.53$ & $1.95 \pm 1.02$ & $1.75 \pm 0.28$ & $2.13 \pm 1.01$ & $2.30 \pm 1.26$ & $1.84 \pm 0.58$ & $1.97 \pm 1.25$ & $2.04 \pm 0.60$ & $2.31 \pm 1.25$ \\
\hline$C h l_{a+b}\left(m g \cdot g_{D W}^{-1}\right)$ & $8.39 \pm 1.10$ & $7.70 \pm 1.53$ & $7.65 \pm 0.85$ & $7.95 \pm 1.36$ & $8.05 \pm 2.05$ & $7.25 \pm 1.07$ & $7.14 \pm 1.81$ & $7.72 \pm 1.31$ & $7.94 \pm 2.19$ \\
\hline
\end{tabular}


Table 2: The second model variable alternately tested depending investigated on ecological processes.

\begin{tabular}{|c|c|c|}
\hline Group & Variables & Ecological processes \\
\hline Extreme temperatures & $T_{\text {mean }(t, s)}$ & Impacts of low or high temperatures? \\
\hline Dessication & $I_{\text {time }(t, s)}$ & Impacts of dessication? \\
\hline \multirow{2}{*}{ Hydrodynamics } & $V_{75(s)}$ & \multirow{2}{*}{ Impacts of currents or waves? } \\
\hline & $R E I_{75(t, s)}$ & \\
\hline \multirow{2}{*}{ Hydrology } & $F_{\text {sea(s) }}$ & \multirow{2}{*}{ Impacts of oceanic or rivers waters? } \\
\hline & $F_{r i v(s)}$ & \\
\hline \multirow{3}{*}{ Bed sediment } & $D_{50(t, s, r)}$ & \multirow{3}{*}{ Impacts of bed sediment characteristics? } \\
\hline & $\rho_{\text {dry }(t, s, r)}$ & \\
\hline & $O M_{\text {sed }(t, s, r)}$ & \\
\hline Vegetation & $V_{\text {area }(t, s)}$ & Threshold effects on vegetated area? \\
\hline
\end{tabular}

